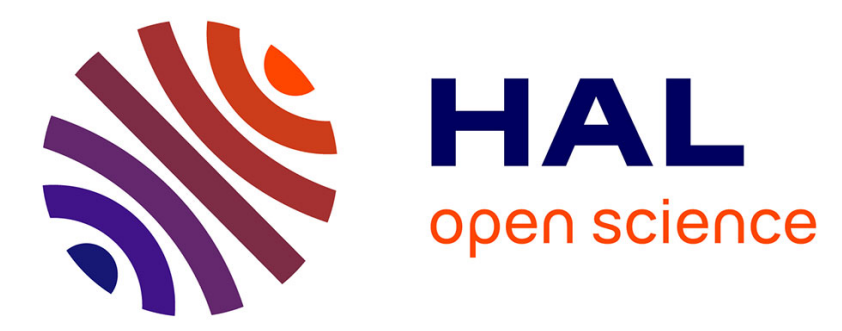

\title{
Detailed Understanding of the DBU/CO 2 Switchable Solvent System for Cellulose Solubilization and Derivatization
}

Kelechukwu Onwukamike, Thierry Tassaing, Stéphane Grelier, Etienne Grau, Henri Cramail, Michael Meier

\section{To cite this version:}

Kelechukwu Onwukamike, Thierry Tassaing, Stéphane Grelier, Etienne Grau, Henri Cramail, et al.. Detailed Understanding of the DBU/CO 2 Switchable Solvent System for Cellulose Solubilization and Derivatization. ACS Sustainable Chemistry \& Engineering, 2017, 6 (1), pp.1496-1503. 10.1021/acssuschemeng.7b04053 . hal-01917963

\section{HAL Id: hal-01917963 \\ https://hal.science/hal-01917963}

Submitted on 21 Nov 2019

HAL is a multi-disciplinary open access archive for the deposit and dissemination of scientific research documents, whether they are published or not. The documents may come from teaching and research institutions in France or abroad, or from public or private research centers.
L'archive ouverte pluridisciplinaire HAL, est destinée au dépôt et à la diffusion de documents scientifiques de niveau recherche, publiés ou non, émanant des établissements d'enseignement et de recherche français ou étrangers, des laboratoires publics ou privés. 


\title{
Detailed Understanding of the $\mathrm{DBU} / \mathrm{CO}_{2}$ Switchable Solvent System for Cellulose Solubilization and Derivatization
}

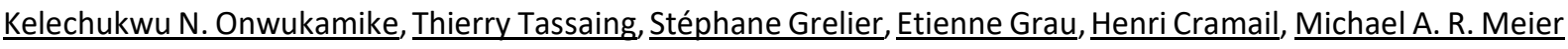

\begin{abstract}
:
In this article, we present an optimization study of the switchable solvent system $\mathrm{DBU} / \mathrm{CO}_{2}$ for cellulose solubilization and derivatization via online Fourier transform infrared spectroscopy (FT-IR). By varying temperature, $\mathrm{CO}_{2}$ pressure, and solubilization time, we succeeded in achieving cellulose solubilization within 10$15 \mathrm{~min}$ at $30^{\circ} \mathrm{C}$. Compared to traditionally used ionic liquids, the system presented here is cheaper, is easier to recycle, and enables a very fast cellulose solubilization under mild conditions. The efficiency of our optimized mild conditions were further confirmed by X-ray diffraction (XRD) experiments showing the typical transformation from cellulose I to II upon regeneration. In addition, we prove the existence of the in situ formed carbonate anions by trapping them with benzyl bromide or methyl iodide as electrophiles, leading to the successful synthesis of cellulose benzyl carbonate and cellulose methyl carbonate, respectively, under utilization of $\mathrm{CO}_{2}$ as a renewable building block for cellulose derivatization. The synthesized cellulose carbonates were characterized by $\mathrm{FT}-\mathrm{IR},{ }^{1} \mathrm{H} N \mathrm{NMR}$, and ${ }^{13} \mathrm{C}$ NMR spectroscopy. A degree of substitution (DS) value of 1.06 was achieved for the cellulose benzyl carbonate as determined by ${ }^{31} \mathrm{P}$. This study thus provides deep insight into the possibilities of the studied switchable solvent system for cellulose solubilization and offers unprecedented possibilities for novel derivatization protocols of cellulose.
\end{abstract}

\section{Synopsis}

We studied the $\mathrm{DBU} / \mathrm{CO}_{2}$ switchable solvent system in detail and achieved cellulose solubilization within 10-15 min at $30{ }^{\circ} \mathrm{C}$ and moderately low pressures; the reversibly formed carbonate anion was trapped using electrophiles, thus unambigously confriming its existence.

\section{Introduction}

In recent years, the academic interest in renewable resources steadily increased owing to the depletion of nonsustainable, fossil resources as well as the realized need for more sustainable approaches, especially for polymeric materials. As the most abundant biobased organic polymer, cellulose has received considerable attention in this regard. Although it has been employed as a key raw material in the chemical industry for over a century, its vast potential is seriously limited due to a solubility issue.(1) The insolubility of cellulose in most common solvents can be attributed to its crystallinity due to strong intra- and inter-molecular hydrogen bonds.(2) Only solvents capable of disrupting or breaking these $\mathrm{H}$-bonds are able to solubilize cellulose.(1) During the last few decades, various solvents have been investigated for this purpose. Examples include $N, N$ dimethylacetamide lithium chloride (DMAc-LiCl),(3) $N$-methylmorpholine $N$-oxide (NMMO),(4) and dimethyl sulfoxide tetrabutyl ammonium fluoride (DMSO-TBAF).(5) These solvents suffer from some limitations, including difficult recovery and toxicity. In terms of sustainability, solvents showing a low vapor pressure and recyclability are desirable. In this context, in 2002 Swatloski et al. showed the potential of ionic liquids, such as 1-butyl-3methylimidazolium chloride (BMIMCl), as a green solvent for cellulose solubilization.(6) After their publication, an extensive research interest in the field of ionic liquids for cellulose chemistry can be noted.(7) Despite the huge potential of ionic liquids, the latter suffer from some limitations, notably their high cost and easy contamination in some reactions, which makes their recovery difficult in many cases.(8) Furthermore, high 
temperatures $\left(>70^{\circ} \mathrm{C}\right.$ ) and long reaction times $(>8 \mathrm{~h}$ ) are usually required for complete cellulose solubilization with lower solubilization time achievable via microwave irradiation.(6) In 2005, Jessop and his group described the concept of $\mathrm{a} \mathrm{CO}_{2}$ switchable solvent system as a solvent capable of being transformed from a nonionic to an ionic state by application of $\mathrm{CO}_{2}$, with the possibility to revert to its initial nonionic state by $\mathrm{CO}_{2}$ removal.(9) This idea was simultaneously applied by Xie et al.(10) and Zhang et al.(11) for the solubilization of cellulose. Thus, in the presence of a super base and $\mathrm{CO}_{2}$ with dimethyl sulfoxide (DMSO) as cosolvent, cellulose was solubilized in a nonderivative approach (wherein an alcohol carbonate-DMSO system is formed, which is a good solvent for cellulose) or a derivative approach (whereby cellulose is directly transformed into a carbonate in the presence of $\mathrm{CO}_{2}$, which is soluble in DMSO) (Scheme 1).

\section{Strategy I: Non-derivative dissolution}

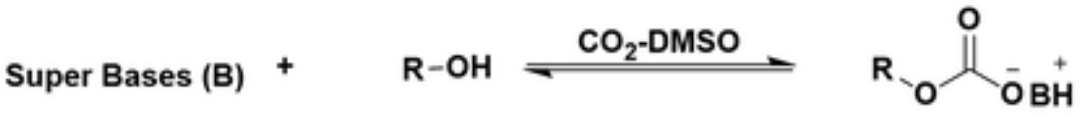

\section{Strategy II: Derivative dissolution}

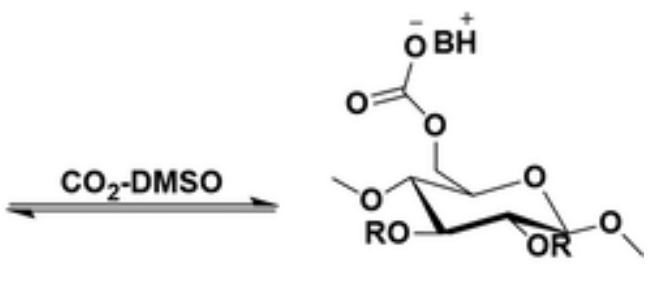

Super Bases (B)
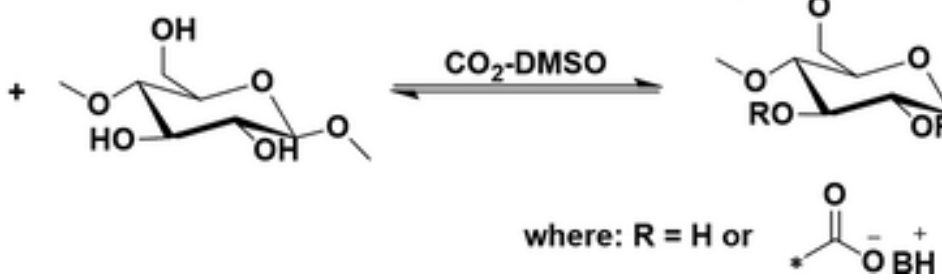

Scheme 1. Proposed Solubilization of Cellulose in $\mathrm{CO}_{2}$ Switchable Solvent; Adapted from Xie et al.(10) and Zhang et al.(11)

These authors independently showed complete cellulose solubilization in this solvent system in $1-3 \mathrm{~h}$ at temperatures ranging from 50 to $60^{\circ} \mathrm{C}$, at $\mathrm{CO}_{2}$ pressures ranging from 2 to 8 bar. To achieve solubilization within a shorter reaction time (below $30 \mathrm{~min}$ ) at temperatures ranging between 40 and $60^{\circ} \mathrm{C}$, Nanta et al. showed that a $\mathrm{CO}_{2}$ pressure of above 50 bar was required.(12) Wang et al. succeeded to achieve cellulose solubilization at 30 ${ }^{\circ} \mathrm{C}$ using a $\mathrm{CO}_{2}$ pressure below 10 bar, but longer reaction times between 1 and $5 \mathrm{~h}$ were required.(13) Compared to typical ionic liquids, the $\mathrm{CO}_{2}$ switchable solvent system is more advantageous, because it can be more easily recycled and needs lower temperature and time for cellulose solubilization. Recently, various modifications of cellulose in this solvent system demonstrated its potential for the synthesis of cellulose derivatives. For instance, the acylation of cellulose in this switchable solvent led to a comparable higher degree of substitution (DS) at more moderate conditions compared to classic ionic liquids.(14) Also reported recently is the grafting "from" cellulose with lactides, leading to high grafting densities.(15) Furthermore, the versatility of this solvent system has been shown as a promising reversible $\mathrm{CO}_{2}$-capture agent.(16) However, still absent in the literature are studies describing not only the optimization of the temperature and the reaction time but also the lowering of the required $\mathrm{CO}_{2}$ pressure. Such an optimization would lead to an increase in sustainability of the solvent system, as less energy cost will be required during the solubilization process and, more importantly, the need for special equipment withstanding high pressures would be obsolete.

Moreover, the proposed mechanism of cellulose solubilization in the derivative approach occurs via cellulose premodification into its carbonate anion upon reacting with $\mathrm{CO}_{2}$ in the presence of a super base. Until today, the conclusive presence of this in situ carbonate intermediate is yet to be proven beyond results from FT-IR measurements and proton and carbon NMR. The validity of such methods is limited due to the reaction of adventitious water (present in super bases and in cellulose) with $\mathrm{CO}_{2}$.(17) Hence, a conclusive proof would be 
the isolation of a derivative of this intermediate carbonate. Such a proof would also lead to novel approaches for cellulose derivatization.

Herein, we thus focus on the use of diazabicyclo [5.4.0]-undec-7-ene (DBU) as a super base and study the influence of reaction time, temperature, and $\mathrm{CO}_{2}$ pressure on the cellulose solubilization in detail. In addition, we investigated the derivatization of the in situ generated carbonate in order to unambiguously prove its existence.

\section{Experimental Section}

Materials

Microcrystalline cellulose (MCC) was obtained from Sigma-Aldrich and dried at $100^{\circ} \mathrm{C}$ for $24 \mathrm{~h}$ under vacuum to remove water before use. The following chemicals were used without further purification. 2-Chloro-4,4,5,5tetramethyl-1,3,2-dioxaphospholane (TMDP, 95\%) was purchased from Sigma-Aldrich. Deuterated chloroform $\left(\mathrm{CDCl}_{3}-d\right)$ and deuterated dimethyl sulfoxide (DMSO- $d_{6}$ ) were purchased from Merck. Diazabicyclo[5.4.0]undec7-ene (DBU, >98\%, TCI), 1,1,3,3-tetramethylguanidine (TMG, 99\%, abcr), 7-methyl-1,5,7-triazabicyclo[4.4.0]-dec5-ene (MTBD, 98\%, Sigma-Aldrich), methyl iodide (>99.9\%, VWR), benzyl bromide (98\%, Sigma-Aldrich), and octanol (99\%, Acros Organics) were also used without further purification. Carbon dioxide $\left(\mathrm{CO}_{2}\right.$, Air Liquide, $>99.9 \%$ ), dimethyl sulfoxide (DMSO, VWR, 99\%), ethyl acetate, and methanol were in technical grades and used without further purification.

\section{Methods}

\section{In Situ Fourier Transform Infrared Spectroscopy}

The optimization study on the $\mathrm{CO}_{2} / \mathrm{DBU}$ solvent system was monitored in situ with high-pressure attenuated total reflectance-infrared (ATR-IR) spectroscopy. Single-beam spectra were recorded within the frequency range $\left(400-4000 \mathrm{~cm}^{-1}\right)$ with a $4 \mathrm{~cm}^{-1}$ resolution. Thirty scans were collected for each measurement.

\section{ATR Setup Description}

The ATR setup used was similar to our previous work.(18) Briefly explained, the ATR setup consists of a homemade Ge ATR accessory with capacity to measure under high temperatures (up to $150^{\circ} \mathrm{C}$ ) and under high pressures (up to 50 bar of $\mathrm{CO}_{2}$ ), coupled with a ThermoOptek interferometer (type 6700) equipped with a globar source, a $\mathrm{KBr} / \mathrm{Ge}$ beamsplitter, and a DTGS (deuterated triglycine sulfate) detector. The sample holder consists of a stainless steel cell ( $3 \mathrm{~mL}$ volume) screwed above the Ge crystal. Homogeneity inside the cell was achieved by addition of a magnetic stirrer. Cartridge heaters located around the ATR cell and a thermocouple regulated the temperature with an accuracy of $2{ }^{\circ} \mathrm{C}$. The $\mathrm{CO}_{2}$ inlet located above the cell was connected directly to a $\mathrm{CO}_{2}$ tank, allowing introduction and control of the pressure.

\section{Sample Preparation}

Three percent ( $w / w$ ) of cellulose and DBU (3 equiv per anhydroglucose unit of cellulose) were agitated in $1 \mathrm{~mL}$ of DMSO at room temperature for a few minutes and transferred to the ATR cell. To evaluate the effect of temperature, the $\mathrm{CO}_{2}$ pressure was kept constant while the temperature was varied $\left(30,40,50\right.$, and $\left.60{ }^{\circ} \mathrm{C}\right)$. Equally, for the investigation of the effect of $\mathrm{CO}_{2}$ pressure, the temperature was kept constant while the $\mathrm{CO}_{2}$ pressure was varied $(5,10,20$, and $40 \mathrm{bar}$ ). After setting the required parameters (temperature and $\mathrm{CO}_{2}$ pressure), the characteristic symmetric stretching vibration bands of $\mathrm{C}=0\left(1665 \mathrm{~cm}^{-1}\right)$ of the in situ formed carbonate, $\mathrm{C}=\mathrm{N}\left(1614 \mathrm{~cm}^{-1}\right)$ of $\mathrm{DBU}$ and $\mathrm{C}=\mathrm{N}-\mathrm{H}^{+}\left(1639 \mathrm{~cm}^{-1}\right)$ of its protonated form, were monitored during the optimization study. 
Three different super bases were used: diazabicyclo[5.4.0]undec-7-ene (DBU), 7-methyl-1,5,7triazabicyclo[4.4.0]dec-5-ene (MTBD), and 1,1,3,3-tetramethylguanidine (TMG). During the measurement, 3\% $(w / w)$ of cellulose, DBU (3 equiv per anhydroglucose unit of cellulose), and $1 \mathrm{~mL}$ of DMSO were first agitated for a few minutes at room temperature and then transferred to the ATR cell. Next, 20 bar of $\mathrm{CO}_{2}$ were applied and the temperature was increased from 30 to $80{ }^{\circ} \mathrm{C}$ with a $10{ }^{\circ} \mathrm{C}$ step followed by a cooling back to $30{ }^{\circ} \mathrm{C}$, while monitoring the intensity of $\mathrm{C}=\mathrm{O}$ symmetric absorbance band $\left(1665 \mathrm{~cm}^{-1}\right)$ of the in situ carbonate. At each temperature $\left(30,40,50,60,70\right.$, and $\left.80^{\circ} \mathrm{C}\right)$, two measurements were recorded, the first after the set temperature has been stabilized and the second after $3 \mathrm{~min}$. The mean value of both measurements was then calculated. The same procedure was employed for investigation using octanol.

\section{Influence of the Cellulose Concentration}

The cellulose concentration was varied from $0.9 \%(\mathrm{w} / \mathrm{w})(10 \mathrm{mg} / \mathrm{mL})$ to $7.3 \%(\mathrm{w} / \mathrm{w})(80 \mathrm{mg} / \mathrm{mL})$ in $\mathrm{DMSO}$, and the samples were prepared as previously described. In this case, after preparing the required concentration of cellulose, 20 bar of $\mathrm{CO}_{2}$ were applied while keeping the temperature in the cell at $30{ }^{\circ} \mathrm{C}$ for a period of $15 \mathrm{~min}$, after which the intensity of the $\mathrm{C}=\mathrm{O}$ absorbance peak at $1665 \mathrm{~cm}^{-1}$ was collected. To investigate the influence of the temperature at various cellulose concentrations, the required temperature $\left(35,40,50\right.$, and $\left.60^{\circ} \mathrm{C}\right)$ was set before the measurement and maintained during the experiment. The same procedure was equally applied for the experiment using octanol.

\section{Indirect Proof of In Situ Carbonate Formation}

Following a previously published procedure,(19) where the synthesis of mixed carbonates using simple alcohols was reported, we made some modifications to the procedure to adapt it to the $\mathrm{CO}_{2}$ solvent system, leading to the synthesis of mixed carbonates using octanol and cellulose.

\section{Synthesis of Octylbenzyl Carbonate}

Octanol ( $0.50 \mathrm{~g}, 3.8 \mathrm{mmol}, 1.0$ equiv) and DBU (0.58 g, $3.8 \mathrm{mmol}, 1.0$ equiv) were dissolved in DMSO (4.0 mL). The reaction mixture was transferred to a $\mathrm{CO}_{2}$ pressure reactor, and $\mathrm{CO}_{2}\left(5 \mathrm{bar}\right.$ ) was applied for $15 \mathrm{~min}$ at $30{ }^{\circ} \mathrm{C}$. Next, benzyl bromide $\left(7.7 \mathrm{mmol}, 1.3 \mathrm{~g}, 2.0\right.$ equiv) was added, and the reaction was performed under 5 bar $\mathrm{CO}_{2}$ for $1 \mathrm{~h}$ at $30{ }^{\circ} \mathrm{C}$. The crude product was washed with distilled water $(20 \mathrm{~mL})$ and extracted with ethyl acetate (40 $\mathrm{mL})$. The organic phase was washed with distilled water $(4 \times 30 \mathrm{~mL})$, separated, and dried over sodium sulfate. After the solvent was removed under reduced pressure, the product was purified via column chromatography (cyclohexane/ethyl acetate, 15:1). Yield: 30\%. ATR-IR $\left(\mathrm{cm}^{-1}\right)$ : $3032 \mathrm{v}(\operatorname{arom} .=\mathrm{C}-\mathrm{H}), 2967 \mathrm{v}_{s}(\mathrm{C}-\mathrm{H}), 2929 \mathrm{v}_{s}(\mathrm{C}-\mathrm{H})$, $2859 \mathrm{v}_{\mathrm{s}}(\mathrm{C}-\mathrm{H}), 1744 \mathrm{v}(\mathrm{C}=\mathrm{O}), 1255 \mathrm{v}(\mathrm{C}-\mathrm{O}), 1071 \mathrm{v}(\mathrm{C}-\mathrm{O}) .{ }^{1} \mathrm{H}$ NMR $\left(300 \mathrm{MHz}, \mathrm{DMSO}-d_{6}\right) \delta(\mathrm{ppm}): 7.37(\mathrm{~m}, 5 \mathrm{H}), 5.12$ $(\mathrm{m}, 2 \mathrm{H}), 4.08(\mathrm{t}, 2 \mathrm{H}), 1.57(\mathrm{~m}, 2 \mathrm{H}), 1.23(\mathrm{~m}, 10 \mathrm{H}), 0.83(\mathrm{t}, 3 \mathrm{H}) .{ }^{13} \mathrm{C} N M R\left(300 \mathrm{MHz}, \mathrm{DMSO}-d_{6}\right) \delta(\mathrm{ppm}): 154.84$, $135.53,128.40,128.11,128.05,68.69,67.75,31.17,28.34,25.03,21.69,13.78$. Exact mass $(\mathrm{M}+\mathrm{Na})^{+} 287.16$. Obtained (ESI) $287.1619 \mathrm{~g} \mathrm{~mol}^{-1}$.

\section{Synthesis of Cellulose Benzyl Carbonate}

$3 \%(\mathrm{w} / \mathrm{w})$ of microcrystalline cellulose $(0.15 \mathrm{~g}, 0.93 \mathrm{mmol}, 1.0$ equiv) was agitated in DMSO $(5 \mathrm{~mL})$ followed by addition of $\mathrm{DBU}\left(2.8 \mathrm{mmol}, 0.42 \mathrm{~g}, 3.0\right.$ equiv). The reaction mixture was transferred to a $\mathrm{CO}_{2}$ pressure reactor where $\mathrm{CO}_{2}$ was applied at 5 bar for $15 \mathrm{~min}$ at $30^{\circ} \mathrm{C}$, leading to complete solubilization of cellulose. Benzyl bromide ( $4.6 \mathrm{mmol}, 0.79 \mathrm{~g}, 5.0$ equiv) was added, and the reaction was allowed to run under 5 bar $\mathrm{CO}_{2}$ for $1 \mathrm{~h}$ at $30^{\circ} \mathrm{C}$. After the reaction, the homogeneous reaction mixture was precipitated in distilled water $(100 \mathrm{~mL})$. The precipitate was filtered and washed with distilled water $(2 \times 50 \mathrm{~mL})$ and methanol $(2 \times 50 \mathrm{~mL})$. The obtained precipitate was then dried at $60^{\circ} \mathrm{C}$ under vacuum for $24 \mathrm{~h}$ to obtain the desired product as a white powder. Yield: 0.16 g. ATR-IR $\left(\mathrm{cm}^{-1}\right)$ : $3395 \mathrm{v}(\mathrm{O}-\mathrm{H}), 3026 \mathrm{v}($ arom. $=\mathrm{C}-\mathrm{H}), 2884 \mathrm{v}_{\mathrm{s}}(\mathrm{C}-\mathrm{H}), 1740 \mathrm{v}(\mathrm{C}=\mathrm{O})$ of carbonate, $1256 \mathrm{v}(\mathrm{C}-\mathrm{O})$, 
$1023 \mathrm{v}(\mathrm{C}-\mathrm{O})$ glycopyranose of cellulose. ${ }^{1} \mathrm{H}$ NMR $\left(400 \mathrm{MHz}, \mathrm{DMSO}-d_{6}, 80{ }^{\circ} \mathrm{C}\right) \delta(\mathrm{ppm}): 7.38(\mathrm{br}, 5 \mathrm{H}), 5.17(\mathrm{br}, 2 \mathrm{H})$, 5.04-3.12 (br, AGU, 7H). ${ }^{13} \mathrm{C}$ NMR (400 MHz, DMSO-d6, $\left.80{ }^{\circ} \mathrm{C}\right) \delta(\mathrm{ppm}): 153.98,135.10,128.08,127.84,127.57$, $102.40,79.66,79.15,74.71,74.48,74.19,72.88,71.87,68.74,60.24$.

\section{Synthesis of Cellulose Methyl Carbonate}

$3 \%(\mathrm{w} / \mathrm{w})$ of microcrystalline cellulose $(0.15 \mathrm{~g}, 0.93 \mathrm{mmol}, 1.0$ equiv) was agitated in DMSO $(5 \mathrm{~mL})$ followed by addition of $\mathrm{DBU}\left(2.8 \mathrm{mmol}, 0.42 \mathrm{~g}, 3.0\right.$ equiv). The reaction mixture was transferred to a $\mathrm{CO}_{2}$ pressure reactor where $\mathrm{CO}_{2}$ was applied at 5 bar for $15 \mathrm{~min}$ at $30{ }^{\circ} \mathrm{C}$, leading to complete solubilization of cellulose. Methyl iodide ( $4.6 \mathrm{mmol}, 0.66 \mathrm{~g}, 5.0$ equiv) was added, and the reaction was allowed to run under 5 bar $\mathrm{CO}_{2}$ for $1 \mathrm{~h}$ at $30{ }^{\circ} \mathrm{C}$. After the reaction, the homogeneous reaction mixture was precipitated in distilled water $(100 \mathrm{~mL})$. The precipitate was filtered and washed with distilled water $(2 \times 50 \mathrm{~mL})$ and methanol $(2 \times 50 \mathrm{~mL})$. The obtained precipitate was then dried at $60^{\circ} \mathrm{C}$ under vacuum for $24 \mathrm{~h}$ to obtain the desired product as a white powder. Yield: 0.14 g. ATR-IR $\left(\mathrm{cm}^{-1}\right): 3392 \mathrm{v}(\mathrm{O}-\mathrm{H}), 2895 \mathrm{v}_{\mathrm{s}}(\mathrm{C}-\mathrm{H}), 1740 \mathrm{v}(\mathrm{C}=\mathrm{O})$ of carbonate, $1266 \mathrm{v}(\mathrm{C}-\mathrm{O}), 1020 \mathrm{v}(\mathrm{C}-\mathrm{O})$ glycopyranose of cellulose. ${ }^{1} \mathrm{H}$ NMR $\left(400 \mathrm{MHz}, \mathrm{DMSO}-d_{6}, 80{ }^{\circ} \mathrm{C}\right) \delta(\mathrm{ppm}): 5.15-3.19(\mathrm{br}, \mathrm{AGU}, 7 \mathrm{H}), 3.73(\mathrm{br}, 3$ $\left.\mathrm{CH}_{3}\right) .{ }^{13} \mathrm{C}$ NMR $\left(400 \mathrm{MHz}\right.$, DMSO- $\left.d_{6}, 80^{\circ} \mathrm{C}\right) \delta(\mathrm{ppm}): 154.59,154.24,102.40,79.65,79.22,74.71,74.48,72.87$, $71.83,60.23,54.32,54.02,48.22$.

\section{Instruments}

\section{Nuclear Magnetic Resonance Spectroscopy}

${ }^{1} \mathrm{H}$ NMR spectra were recorded using Bruker Prodigy operating at $400 \mathrm{MHz}$ at $80{ }^{\circ} \mathrm{C}$ (for cellulose benzyl carbonate and cellulose methyl carbonate) with 1000 scans and a time delay $d 1$ of $1 \mathrm{~s}$. Data were reported in ppm relative to DMSO- $d_{6}$ at $2.5 \mathrm{ppm} .{ }^{13} \mathrm{C}$ NMR spectra were recorded using a Bruker Prodigy operating at 400 $\mathrm{MHz}$ at $80^{\circ} \mathrm{C}$ with 6000 scans and a time delay $d 1$ of $2 \mathrm{~s}$. Data are reported in ppm relative to DMSO-d6 at 39.52 ppm. For octyl benzyl carbonate, ${ }^{1} \mathrm{H}$ NMR spectra were recorded using Bruker Avance DPX $300 \mathrm{MHz}$ with 64 scans and a time delay $d 1$ of $1 \mathrm{~s}$, and data were reported in ppm relative to DMSO- $d_{6}$ at $2.5 \mathrm{ppm} .{ }^{13} \mathrm{C}$ NMR spectra were recorded using a Bruker Avance DPX 300 with 1024 scans and a time delay d1 of $2 \mathrm{~s}$, and data were reported relative to DMSO- $d_{6}$ at $39.52 \mathrm{ppm}$. All products were dissolved in DMSO- $d_{6}$ with concentrations of $10-20 \mathrm{mg} / \mathrm{mL}$.

\section{${ }^{31}$ P NMR Method for DS Determination}

Degrees of substitution (DSs) were determined by ${ }^{31} \mathrm{P}$ NMR using a Bruker Ascend $400 \mathrm{MHz}$ spectrometer with 1024 scans, a delay time $d 1$ of $5 \mathrm{~s}$, and a spectral width of $90 \mathrm{ppm}$ (190-100 ppm). Samples were prepared according to the following procedure: an exact amount of $25 \mathrm{mg}$ of a sample was weighed and dissolved in $1 \mathrm{~mL}$ of pyridine. Next $1.2 \mathrm{~mL}$ of $\mathrm{CDCl}_{3}$ was added alongside 2-chloro-4,4,5,5-tetramethyl-1,3,2-dioxaphospholane (2$\mathrm{Cl}$-TMDP, $100 \mu \mathrm{L}, 0.63 \mathrm{mmol})$. The solution was allowed to homogenize, after which the internal standard, endo$N$-hydroxy-5-norbornene-2,3-dicarboximide ( $150 \mu \mathrm{L}, 123.21 \mathrm{mM}$ in pyridine/ $\left.\mathrm{CDCl}_{3} 3: 2,0.0154 \mathrm{mmol}\right)$ was added and the solution was stirred for a further $30 \mathrm{~min}$. Then, $600 \mu \mathrm{L}$ of the solution was transferred to an NMR tube. DS values were calculated according to the reported equation.(20)

\section{Viscosity Measurements}

The viscosities of cellulose and octanol were measured using MALVERN Rotational Rheometer KINEXUS lab+. Prior to the viscosity measurement, a solubilized cellulose (MCC) in DMSO/DBU/CO 2 solvent system was prepared with a concentration of $30 \mathrm{mg} / \mathrm{mL}$. The shear rate was increased from 1 to $100 \mathrm{~s}^{-1}$ while measuring the change in shear viscosity (Pa.s). The viscosity of the sample was collected within the stable region of shear viscosity wherein increasing the shear rate led to no observable change in shear viscosity. Similar measurements were done for octanol with the same concentration of $30 \mathrm{mg} / \mathrm{mL}$. 
X-ray diffraction (XRD) patterns were collected on a PANalitycal X'pert MPD-PRO Bragg-Brentano $\theta-\theta$ geometry diffractometer equipped with a secondary monochromator and an $X^{\prime}$ celerator detector over an angular range of $2 \theta=8-80^{\circ}$. Each acquisition lasted for $1 \mathrm{~h}$ and $27 \mathrm{~min}$. The $\mathrm{Cu} \mathrm{K} \alpha$ radiation was generated at $45 \mathrm{kV}$ and $40 \mathrm{~mA}(\lambda$ $=0.15418 \mathrm{~nm}$ ). The regenerated cellulose samples were prepared on silicon wafer sample holders (PANalytical zero background sample holders) and flattened with a piece of glass.

\section{Results and Discussion}

Effect of Temperature on Carbonate Stability

The effect of temperature on the stability of the in situ carbonate formed during the cellulose solubilization (compare Scheme 1) was investigated using three super bases (DBU, MTBD, and TMG). Twenty bar of $\mathrm{CO}_{2}$ pressure was applied, and the temperature was increased from 30 to $80{ }^{\circ} \mathrm{C}$ and then decreased from 80 to $30{ }^{\circ} \mathrm{C}$. The $\mathrm{C}=\mathrm{O}$ absorbance at $1665 \mathrm{~cm}^{-1}$ was followed by in situ FT-IR and plotted as a function of temperature in Figure 1.

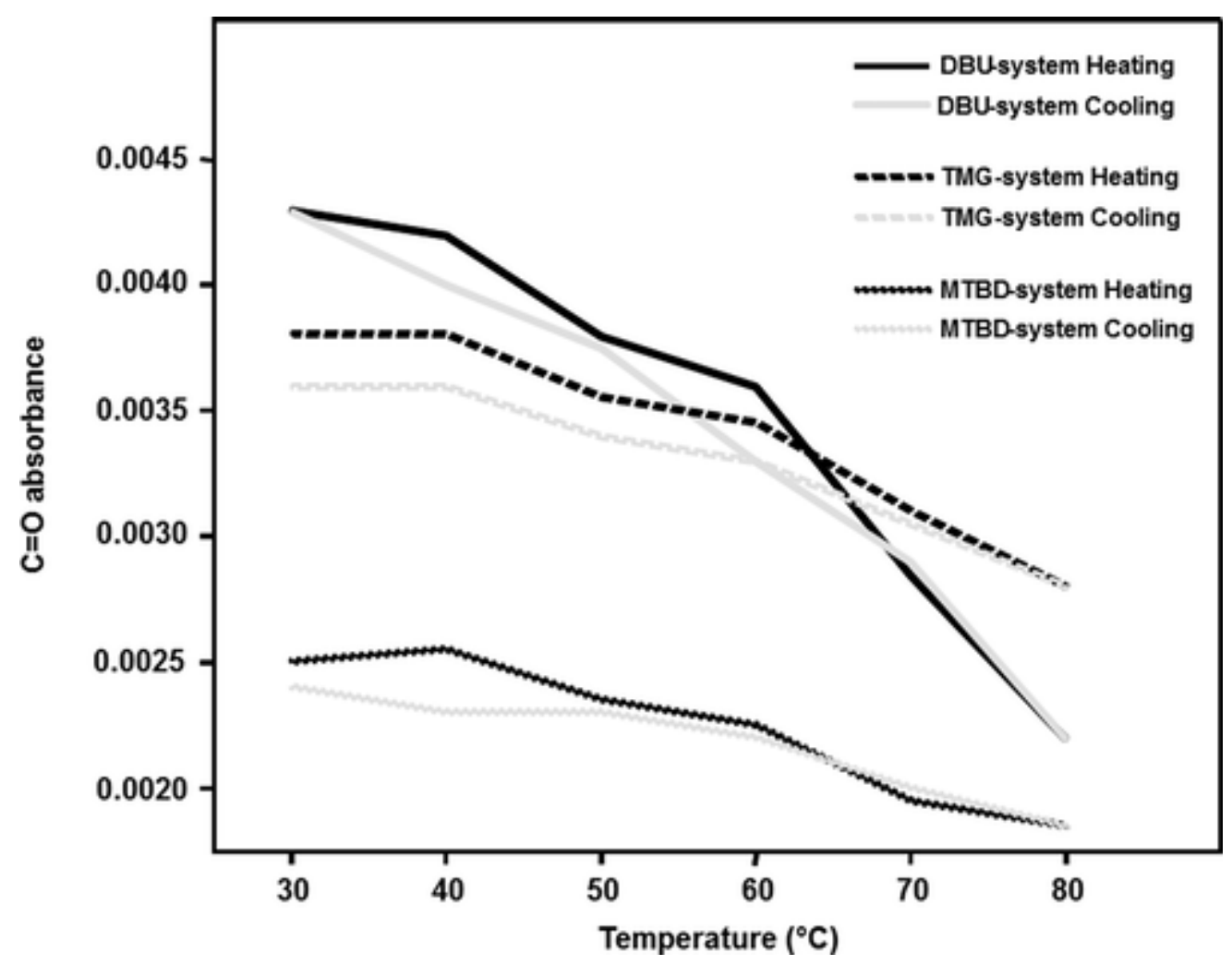

Figure 1. Change of $\mathrm{C}=\mathrm{O}$ absorbance (from the in situ formed carbonate anion) during a temperature cycle study on cellulose solubilization using DBU, MTBD, and TMG as super bases (compare also Scheme 1).

For all the investigated super bases, the intensity of the $\mathrm{C}=\mathrm{O}$ absorbance band of the formed carbonate decreased, as temperature was increased from 30 to $80^{\circ} \mathrm{C}$. Interestingly, as the system was cooled from 80 to $30^{\circ} \mathrm{C}$, the intensity of the $\mathrm{C}=\mathrm{O}$ absorbance band increased again, reaching its respective initial value. This can be explained if we consider the results reported by Heldebrant et al., who showed that reaction between $\mathrm{CO}_{2}$ and a super base in the presence of a proton donor (alcohols) or cellulose in this case are exothermic.(21) In addition, the dissolution of cellulose in the ionic liquid 1-ethyl-3-methylimidazolium acetate (EMIMAC) has equally been shown to be exothermic.(22) Following Le Chatelieŕs principle, for an exothermic reaction at equilibrium, increasing temperature will shift the equilibrium to the starting reactants. This explains why at higher temperatures less carbonate formation occurred. In addition, the recovery of the initial $\mathrm{C}=\mathrm{O}$ intensity upon 
cooling confirms the thermal reversibility of the solvent system. Furthermore, for the $\mathrm{DBU} / \mathrm{CO}_{2}$ system, the lowest reaction temperature of $30{ }^{\circ} \mathrm{C}$ showed almost twice the amount of carbonate formed than a reaction temperature of $60^{\circ} \mathrm{C}$. Compared to the other super bases, DBU showed the highest efficiency in the generation of the in situ carbonate but less stability with temperature compared to MTBD or TMG. To verify whether this property was inherent of this class of solvent system, we carried out a model experiment using octanol and obtained similar results (Figure S1 in the Supporting Information). Thus, these two series of experiments suggest that this reversibility tendency with temperature is an inherent property of the $\mathrm{CO}_{2}$ switchable solvent system.

\section{Pressure and Temperature Optimization}

In situ FT-IR analysis was used to monitor the carbonate formation during cellulose solubilization as well as protonation of DBU. As depicted in Figure 2a and b, over the solubilization time, the decreasing absorbance of the $\mathrm{C}=\mathrm{N}$ band of DBU (1614 $\mathrm{cm}^{-1}$; peak assigned by measuring the FT-IR spectra of neat DBU) was associated with a corresponding increase of the $C=0$ peak $\left(1665 \mathrm{~cm}^{-1}\right)$ of the in situ formed carbonate (similar to the value of $1667 \mathrm{~cm}^{-1}$ reported for the same absorption band(13)) along with an increase of the protonated $\mathrm{DBU}\left(\mathrm{C}=\mathrm{NH}^{+}\right)$ peak ( $1639 \mathrm{~cm}^{-1}$; peak assigned by carrying out a model reaction whereby neat DBU was protonated using dilute hydrochloric acid) and the disappearance of the typical DBU $(C=N)$ absorption band at $1614 \mathrm{~cm}^{-1}$. In addition, the protonated $\mathrm{DBUH}^{+}$absorption band peak at $1639 \mathrm{~cm}^{-1}$ is very close to the previous reported value $\left(1644 \mathrm{~cm}^{-}\right.$ $\left.{ }^{1}\right)$.(17) Equally, from Figure 2b, a stabilization in the absorbance intensity values after 15 min can be observed. This is considered as the optimal time for the solubilization of cellulose above which no significant change is observed. In addition, it is worth noting that the $\mathrm{C}=\mathrm{N}$ absorption band peak of DBU $\left(1614 \mathrm{~cm}^{-1}\right)$ does not decrease to zero, implying the availability of unprotonated DBU, which might act as a catalyst for subsequent modifications of cellulose in this solvent system. A visual proof of the solubilization of $3 \%(w / w)$ of microcrystalline cellulose (MCC) can be seen in Figure 2c. The cloudy solution consisting of MCC, DMSO, and DBU is shown on the left before applying $\mathrm{CO}_{2}$. Applying 5 bar of $\mathrm{CO}_{2}$ in $10-15 \mathrm{~min}$ at $30^{\circ} \mathrm{C}$ led to a clear solubilized cellulose solution, as seen on the right of Figure $2 \mathrm{c}$.

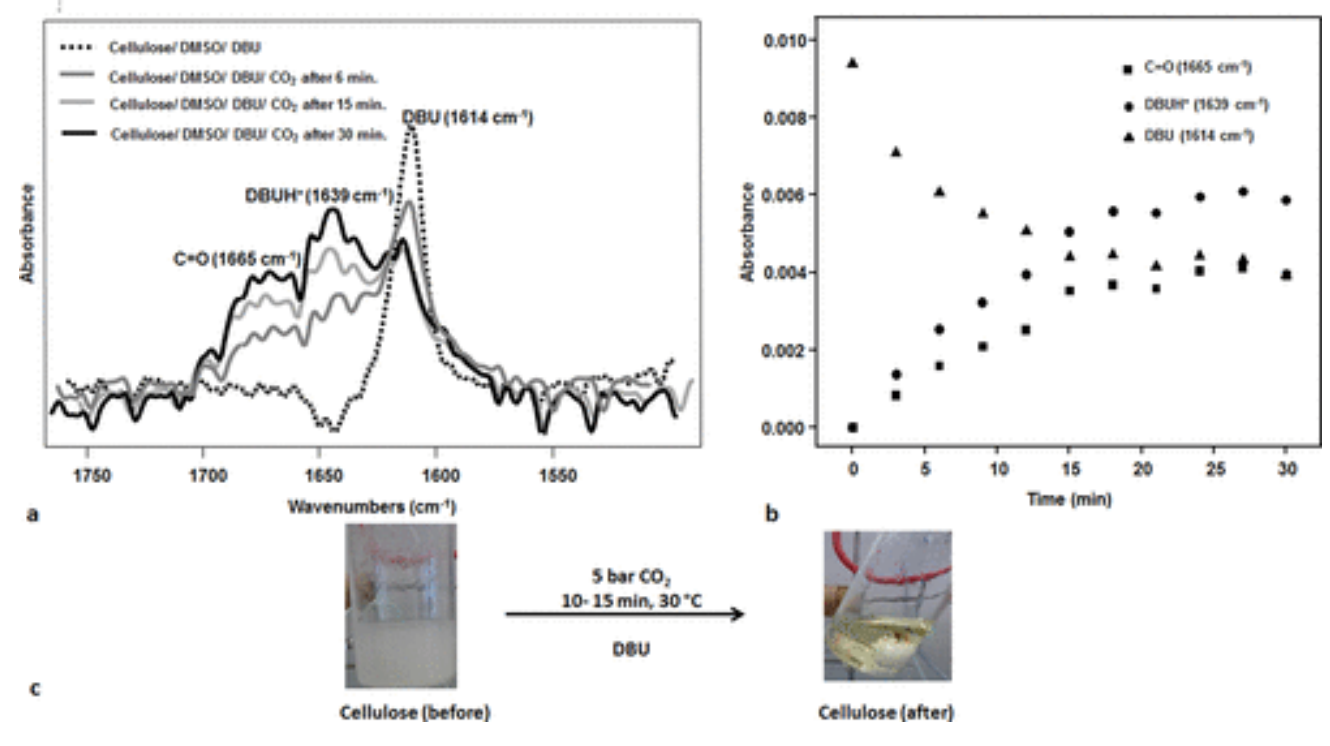

Figure 2. Proof of in situ carbonate formation during cellulose solubilization in $\mathrm{DBU} / \mathrm{CO}_{2}$ solvent. $(\mathrm{a}, \mathrm{b}) \mathrm{FT}-\mathrm{IR}$ showing evolution of $\mathrm{C}=\mathrm{O}, \mathrm{DBU}(\mathrm{C}=\mathrm{N})$, and $\mathrm{DBUH}^{+}\left(\mathrm{C}=\mathrm{NH}^{+}\right)$as a function of time; (c) visual proof for solubilization of cellulose ( $3 \%(\mathrm{w} / \mathrm{w}) \mathrm{MCC}, 30{ }^{\circ} \mathrm{C}, 5$ bar $\left.\mathrm{CO}_{2}, 10-15 \mathrm{~min}\right)$.

The effect of solubilization time at different temperatures (from 30 to $60^{\circ} \mathrm{C}$ ) was then investigated while keeping the $\mathrm{CO}_{2}$ pressure constant. The result of the experiment performed at 5 bar of $\mathrm{CO}_{2}$ is presented in Figure 3 . From the results obtained, the highest carbonate formation was observed at $30{ }^{\circ} \mathrm{C}$. Increasing the temperature led to a relative decrease in the carbonate formation. The investigation results on the effect of temperature at other 
$\mathrm{CO}_{2}$ pressures (10, 20, and 40 bar) are provided in the Supporting Information (Figures S2-S4). The results also showed that whatever the $\mathrm{CO}_{2}$ pressure investigated, increasing the temperature led to a decrease in the carbonate formation, as seen by the decreased intensity of the symmetric $C=0$ stretching vibration band at 1665 $\mathrm{cm}^{-1}$, characteristic of the formed carbonate. This can be attributed to the shift of the equilibrium to the starting reactants, as temperature is increased, typical of an exothermic reaction at equilibrium. Thus, the optimal temperature for the maximum carbonate formed was obtained at $30{ }^{\circ} \mathrm{C}$. In addition, a saturation in carbonate was observed after $\sim 15 \mathrm{~min}$ of reaction time (Figure 3 ).

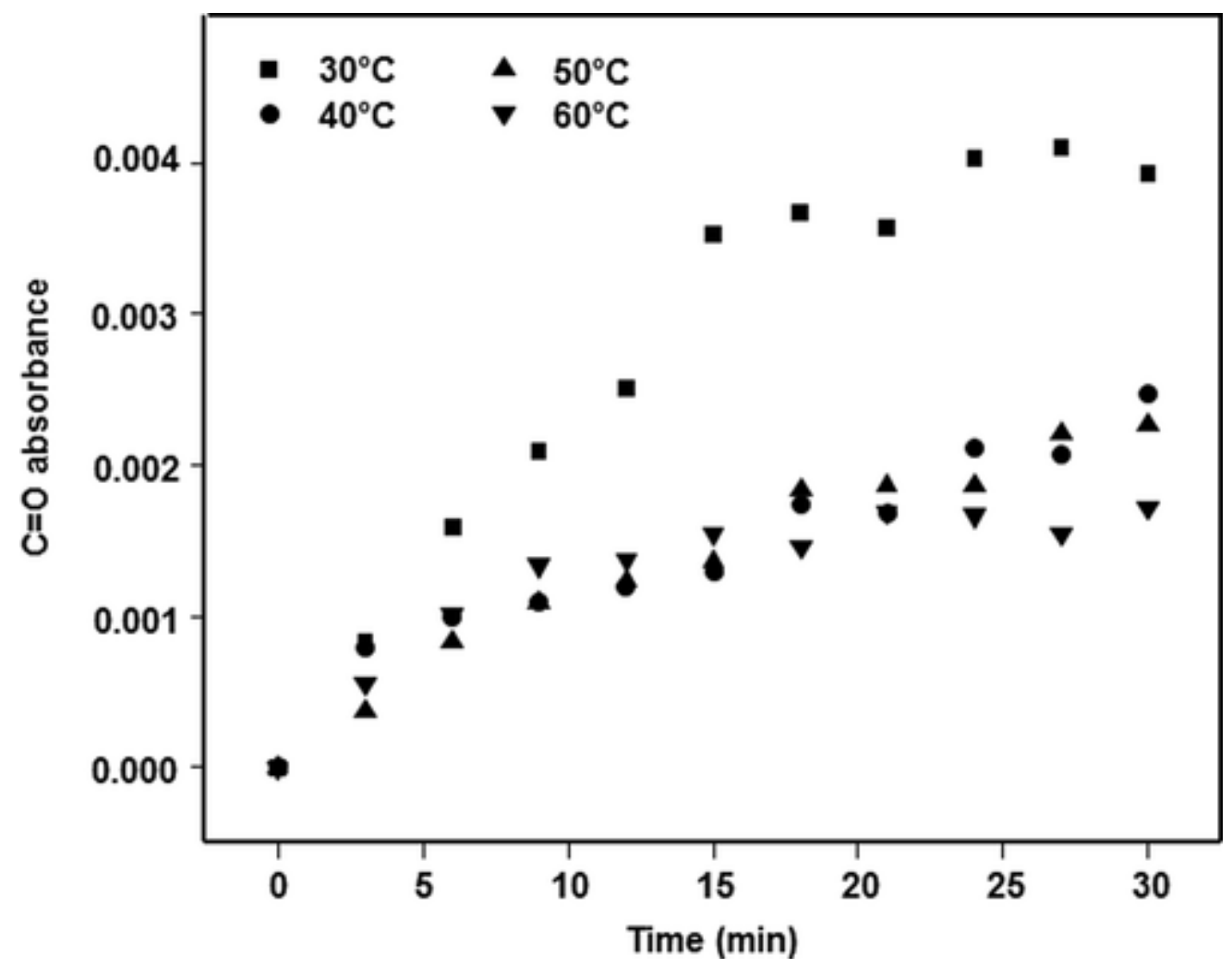

Figure 3. Optimization study via online in situ FT-IR measurement: effect of temperature at 5 bar of $\mathrm{CO}_{2}, 3 \%$ (w/w) MCC.

Furthermore, the effect of $\mathrm{CO}_{2}$ pressure was investigated by increasing it from 5 to 40 bar while keeping the temperature constant. The results from experiments at $30{ }^{\circ} \mathrm{C}$ are presented in Figure 4 and showed that increasing the $\mathrm{CO}_{2}$ pressure led to an increase in the carbonate formation. In addition, increasing the $\mathrm{CO}_{2}$ pressure above 20 bar resulted in an increase in the solubilization kinetics, as evidenced by the rapid attainment of the maximum intensity of the $\mathrm{C}=0$ band in $10 \mathrm{~min}$, whereas at 40 bar, the maximum $\mathrm{C}=0$ intensity was reached within $5 \mathrm{~min}$ (Figure 4). Thus, above 20 bar, it was possible to solubilize cellulose in $<10 \mathrm{~min}$ at 30 ${ }^{\circ} \mathrm{C}$. However, such higher $\mathrm{CO}_{2}$ pressures are not very practical. On the other hand, for $\mathrm{CO}_{2}$ pressures below 20 bar, the solubilization was slower but still finished within $15 \mathrm{~min}$. Further data on investigations at various temperatures are provided in Figures S5-S7. At all investigated temperatures, the general trend of increasing $\mathrm{CO}_{2}$ pressure with an associated increase in carbonate formation was observed. 


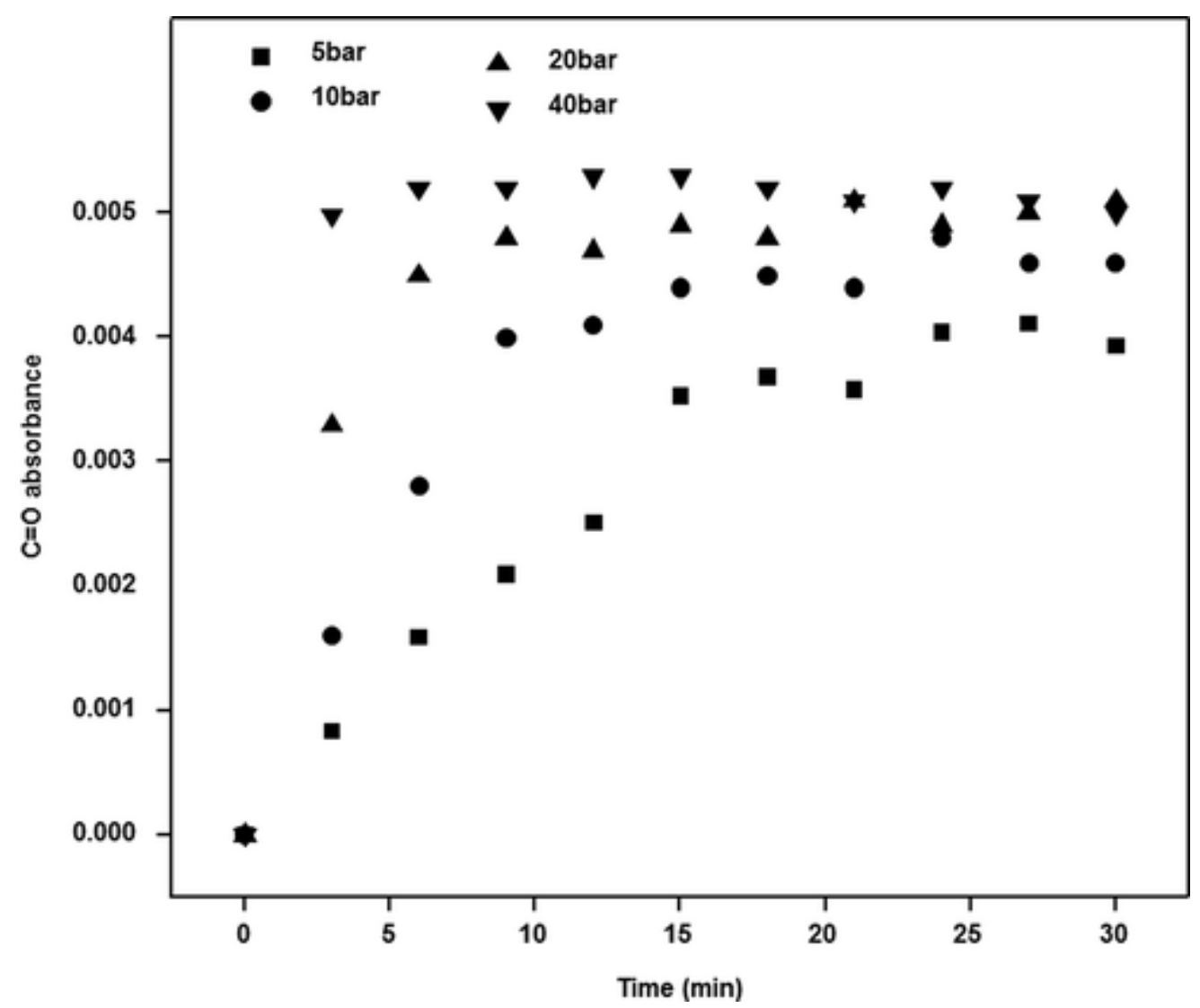

Figure 4. Optimization study via online in situ FT-IR measurement: effect of $\mathrm{CO}_{2}$ pressure at $30{ }^{\circ} \mathrm{C}, 3 \%(\mathrm{w} / \mathrm{w}) \mathrm{MCC}$.

\section{Influence of the Cellulose Concentration}

The concentration of cellulose during solubilization influences the viscosity of the solution and thus its processability. We investigated the effect of cellulose concentration on the carbonate formation by varying the concentration from 10 to $80 \mathrm{mg} / \mathrm{mL}$. The peak intensity of the carbonate absorbance symmetric stretching band at $1665 \mathrm{~cm}^{-1}$ was measured after applying 20 bar of $\mathrm{CO}_{2}$ at $30{ }^{\circ} \mathrm{C}$ for $15 \mathrm{~min}$ (Figure 5). For the lower concentrations of cellulose $(10-40 \mathrm{mg} / \mathrm{mL})$, increasing the cellulose concentration led to a linear increase in carbonate formation, as depicted by an increase in the intensity of the $\mathrm{C}=\mathrm{O}$ absorbance band. However, at higher concentrations $(50-80 \mathrm{mg} / \mathrm{mL})$, a saturation in carbonate was observed. This plateau might be explained by the increase in viscosity, which invariably reduces the stirring rate of the magnetic bar, hence limiting the introduction of $\mathrm{CO}_{2}$ into the DMSO liquid phase. To verify the role of stirring in this cellulose solvent system, a control experiment without stirring was performed. As expected, the solubilization of cellulose did not occur and the characteristic carbonate absorbance at $1665 \mathrm{~cm}^{-1}$ was not detected by FT-IR. However, despite reaching a saturation in carbonate, complete cellulose solubilization was achieved at these higher concentrations. 


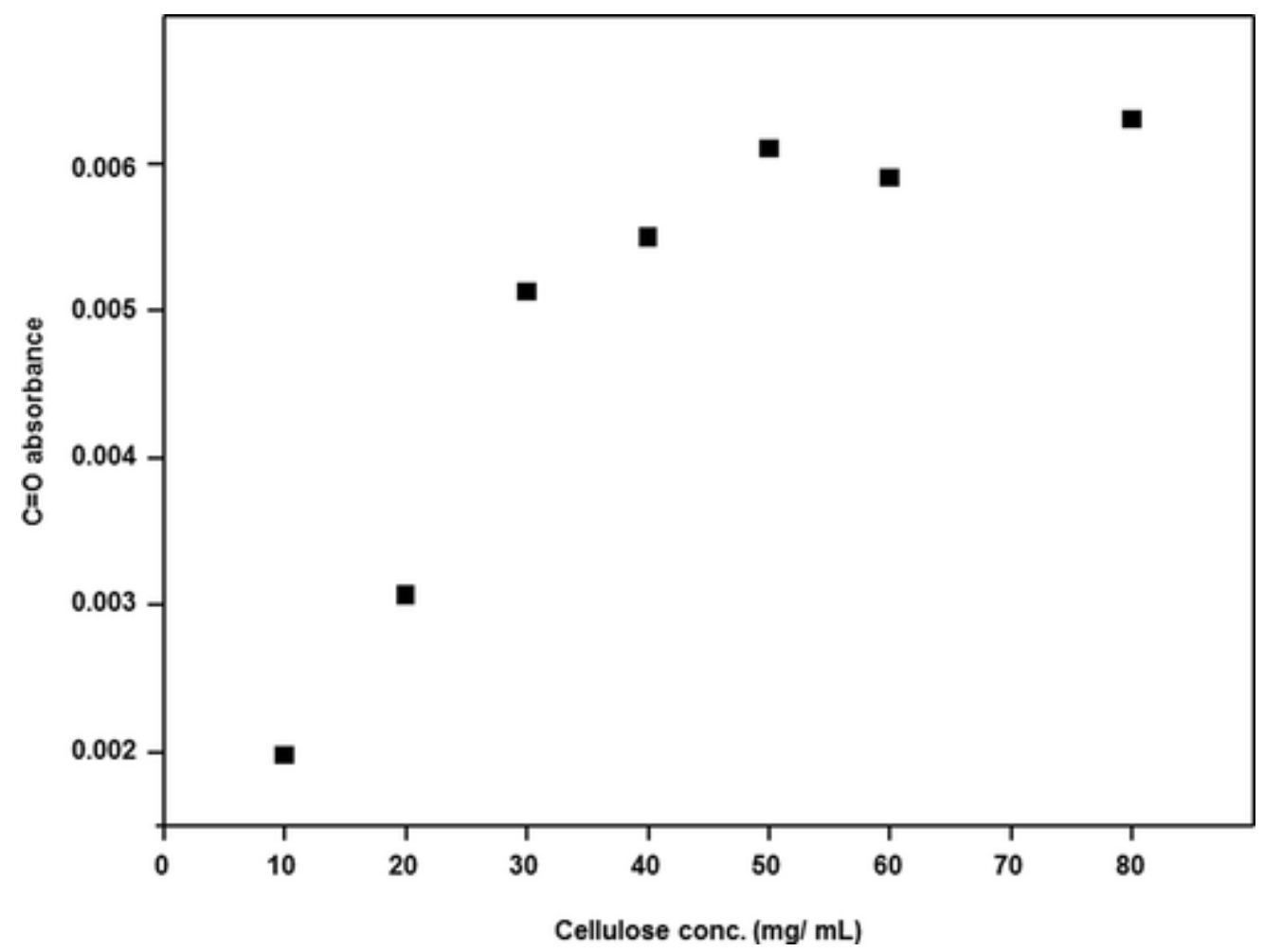

Figure 5. Optimization study via online in situ FT-IR measurement: effect of cellulose concentration (reaction conditions: $30^{\circ} \mathrm{C}, 20$ bar $\mathrm{CO}_{2}$, and $15 \mathrm{~min}$ ).

Furthermore, we investigated the effect of cellulose concentration at higher temperatures $(35,40,50$, and 60 ${ }^{\circ} \mathrm{C}$ ) (Figure S8). The obtained results showed a linear relationship between cellulose concentration and $\mathrm{C}=\mathrm{O}$ intensity. Compared to results performed at $30{ }^{\circ} \mathrm{C}$, no saturation in carbonate was observed, even at higher concentrations of cellulose. This can be associated with the decrease in viscosity upon increasing temperature, which might overcome the limitation observed at $30^{\circ} \mathrm{C}$. The slight reduction observed at $60{ }^{\circ} \mathrm{C}$ is probably due to the increasing effect of temperature on the equilibrium, thereby shifting it to the starting reactants as discussed above. To further verify this viscosity-limiting hypothesis, a model reaction using octanol was carried out. Results showed a linear relationship between octanol concentration $(10-80 \mathrm{mg} / \mathrm{mL})$ and carbonate formation with no carbonate saturation at higher octanol concentrations (Figure S9). Our results of viscosity measurements showed that, for the same concentration of $30 \mathrm{mg} / \mathrm{mL}$, cellulose had a considerably higher viscosity between 7.05 and $7.15 \mathrm{~Pa} \cdot \mathrm{s}$ compared to octanol with a viscosity value between 0.19 and $0.27 \mathrm{~Pa} \cdot \mathrm{s}$ (See Figure S10).

\section{Indirect Proof of In Situ Carbonate Formation}

To trap the intermediate carbonate anion generated during the cellulose solubilization, we first carried out a model reaction using octanol and benzyl bromide as an electrophile. This was successfully achieved, leading to the isolation of octyl benzyl carbonate, thus confirming that the formed carbonate anion acted as a nucleophile in an $\mathrm{S}_{\mathrm{N}} 2$ reaction. The success of the reaction was visible from FT-IR measurement by the appearance of the characteristic symmetric $C=O$ stretching vibration band of carbonic ester at $1745 \mathrm{~cm}^{-1}$ as well as the presence of $\mathrm{C}-\mathrm{O}$ absorbance at $1255 \mathrm{~cm}^{-1}$ arising from the newly formed $\mathrm{C}-\mathrm{O}$ bond between the carbonate carbonyl group and the benzyl carbon of the electrophile (Figure S11). The structure was further confirmed by ${ }^{1} \mathrm{H} N M R$ and ${ }^{13} \mathrm{C}$ NMR (Figures S12 and S13). Furthermore, from electrospray ionization (ESI) the exact mass ((M $+\mathrm{Na})^{+} 287.16 \mathrm{~g}$ $\left.\mathrm{mol}^{-1}\right)$ of the octyl benzyl carbonate was confirmed $\left((\mathrm{M}+\mathrm{Na})^{+} 287.1619 \mathrm{~g} \mathrm{~mol}^{-1}\right)$. 
Upon transferring the reaction to cellulose, we synthesized the corresponding cellulose benzyl carbonate. The appearance of the symmetric $\mathrm{C}=\mathrm{O}$ stretching vibration band of carbonate ester at $1740 \mathrm{~cm}^{-1}$ confirmed the success of the reaction. Also present was the new $\mathrm{C}-\mathrm{O}$ symmetric absorption band at $1256 \mathrm{~cm}^{-1}$ (Figure 6).
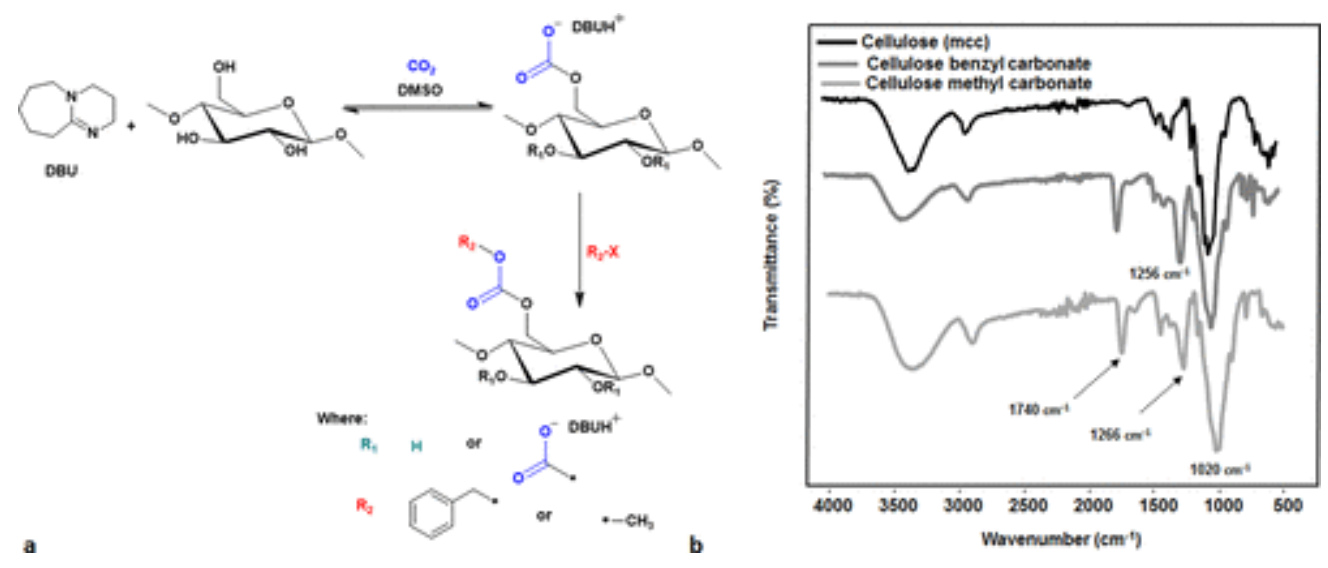

Figure 6. (a) Synthetic scheme for trapping the in situ generated carbonate anion. (b) FT-IR spectra of synthesized cellulose carbonate (methyl and benzyl). Spectra are normalized with the intensity of the glycopyranose oxygen absorption at $1020 \mathrm{~cm}^{-1}$.

In addition, the obtained cellulose carbonate was soluble in DMSO, hence allowing ${ }^{1} \mathrm{H} N M R$ and ${ }^{13} \mathrm{C}$ NMR measurements to further confirm the structure. The ${ }^{1} \mathrm{H}$ and ${ }^{13} \mathrm{C} N M R$ for cellulose benzyl carbonate are shown in Figure 7. The obvious presence of the introduced aromatic group is seen as a broad signal at chemical shift $7.38 \mathrm{ppm}$. Compared to the aromatic region of the benzyl bromide starting compound, there is a significant difference, as can be expected due to the change in the environment of these aromatic protons after coupling to cellulose. In addition, the benzylic $\mathrm{CH}_{2}$ protons are slightly moved toward the lower field (5.17 ppm) in the cellulose carbonate when compared to the benzylic $\mathrm{CH}_{2}$ in the benzyl bromide (4.69 ppm). The broad signals between 3.12 and $5.04 \mathrm{ppm}$ are attributed to the cellulose backbone protons. In addition, from the ${ }^{13} \mathrm{C} N \mathrm{NM}$, the presence of the carbonate carbonyl peak is seen at $154.98 \mathrm{ppm}$ alongside the quaternary carbon of the aromatic ring $(135.10 \mathrm{ppm})$ and the aromatic carbons $(128.08,127.84$, and $127.57 \mathrm{ppm})$. The assigned ${ }^{1} \mathrm{H}$ and ${ }^{13} \mathrm{C}$ NMR peaks of the obtained cellulose benzyl carbonate are similar to results reported for cellulose phenyl carbonate.(23)
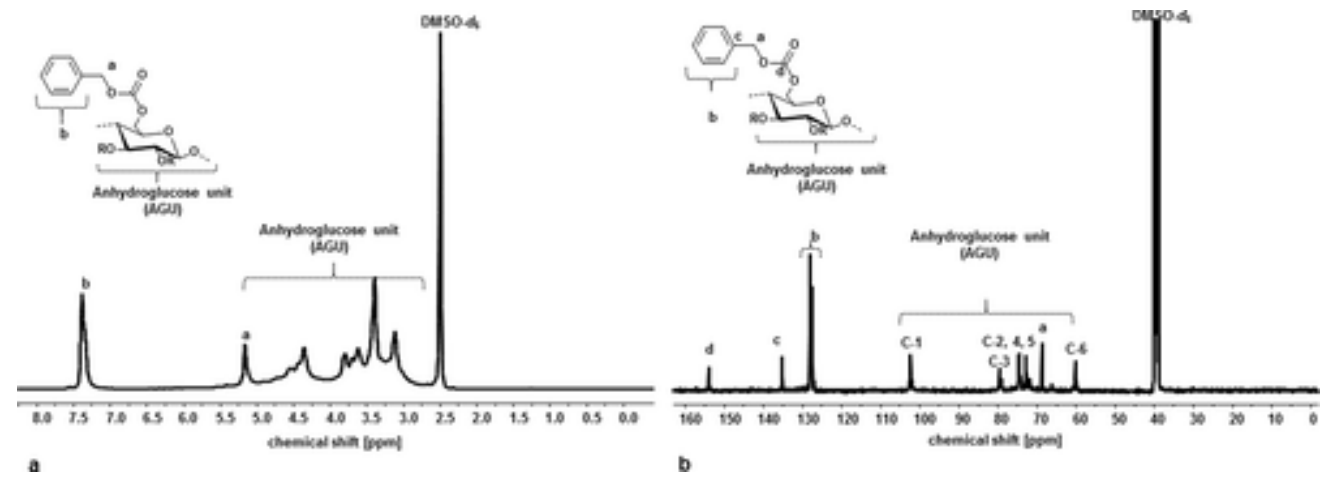

Figure 7. $(\mathrm{a}, \mathrm{b}){ }^{1} \mathrm{H}$ and ${ }^{13} \mathrm{C}$ NMR of cellulose benzyl carbonate in DMSO $\left(d_{6}\right)$.

The degree of substitution (DS) of the cellulose benzyl carbonate was calculated from ${ }^{31} \mathrm{P}$ NMR following a reported procedure.(20) The unreacted hydroxyl groups of cellulose were allowed to react with a phosphorylating agent, revealing a broad signal between 137.0 and $145.0 \mathrm{ppm}$, whose integration relative to an internal standard is employed for DS calculation (see Figure S14). We calculated a DS value of 1.06 for the cellulose benzyl carbonate. 
To show the scope of this reaction, we also trapped the carbonate using methyl iodide as an electrophile. The obtained cellulose methyl carbonate gave similar characteristic FT-IR peaks at $1740 \mathrm{~cm}^{-1}$ (Figure 6). The product was soluble in DMSO, allowing further structure confirmation via ${ }^{1} \mathrm{H}$ and ${ }^{13} \mathrm{C}$ NMR (see Figures S15 and S16). The assigned ${ }^{1} \mathrm{H}$ and ${ }^{13} \mathrm{C}$ NMR peaks for our synthesized methyl cellulose carbonate are similar to those in a previous report that synthesized the same compound using dimethylcarbonate in ionic liquid.(24) Hence, we showed for the first time conclusive evidence of the presence of such intermediate carbonate anions during the cellulose solubilization in the investigated switchable solvent system. In the future, the confirmation of this intermediate carbonate offers the possibility to investigate and design novel modification protocols for cellulose, including, but not at all limited to, the herein demonstrated cellulose carbonate synthesis under $\mathrm{CO}_{2}$ utilization.

\section{XRD Measurements}

Solubilization of cellulose followed by regeneration leads to a change in its crystal structure (crystallinity). X-ray diffraction (XRD) is the method of choice to evaluate this change. X-ray measurements have been previously employed to characterize regenerated cellulose from ionic liquids.(25) Similarly, Xie et al. showed a complete transformation of the native cellulose from cellulose I to II after regeneration in distilled water, employing a nonderivative $\mathrm{CO}_{2}$ switchable solvent system for cellulose solubilization $\left(60^{\circ} \mathrm{C}, 2 \mathrm{~h}\right)$.(10) The change in the crystal structure of cellulose upon regeneration from cellulose I to II reveals the efficiency of the solubilizing solvent. In this regard, we evaluated the effect of temperature and solubilization time on the crystal structure of the regenerated cellulose. Using $\mathrm{DBU}$, we investigated the effect of solubilization temperature ( 30 and $60{ }^{\circ} \mathrm{C}$ ) and reaction time (15 and $60 \mathrm{~min}$ ). After solubilization, cellulose regeneration was performed by precipitation in distilled water followed by drying under vacuum at $60^{\circ} \mathrm{C}$ for $24 \mathrm{~h}$. The dried samples were then analyzed by XRD (Figure 8). The disappearance of characteristic cellulose I diffraction $2 \theta$ peaks at $15.4^{\circ}$ and $22.6^{\circ}$ followed by the appearance of characteristic cellulose II $2 \theta$ peaks at $12.2^{\circ}, 20.1^{\circ}$, and $21.6^{\circ}$ indicates the transformation of the native cellulose from cellulose I to II. Furthermore, no obvious difference was observed in the crystal structure when solubilization was carried out at 30 or $60^{\circ} \mathrm{C}$ and for a solubilization performed at a longer reaction time of $60 \mathrm{~min}$, compared to our optimized time of $15 \mathrm{~min}$. These results confirm that our optimized mild conditions (30 ${ }^{\circ} \mathrm{C}$ and $15 \mathrm{~min}$ ) are sufficient to achieve complete cellulose solubilization, which in turn allows for performing cellulose modifications in homogeneous solution. 


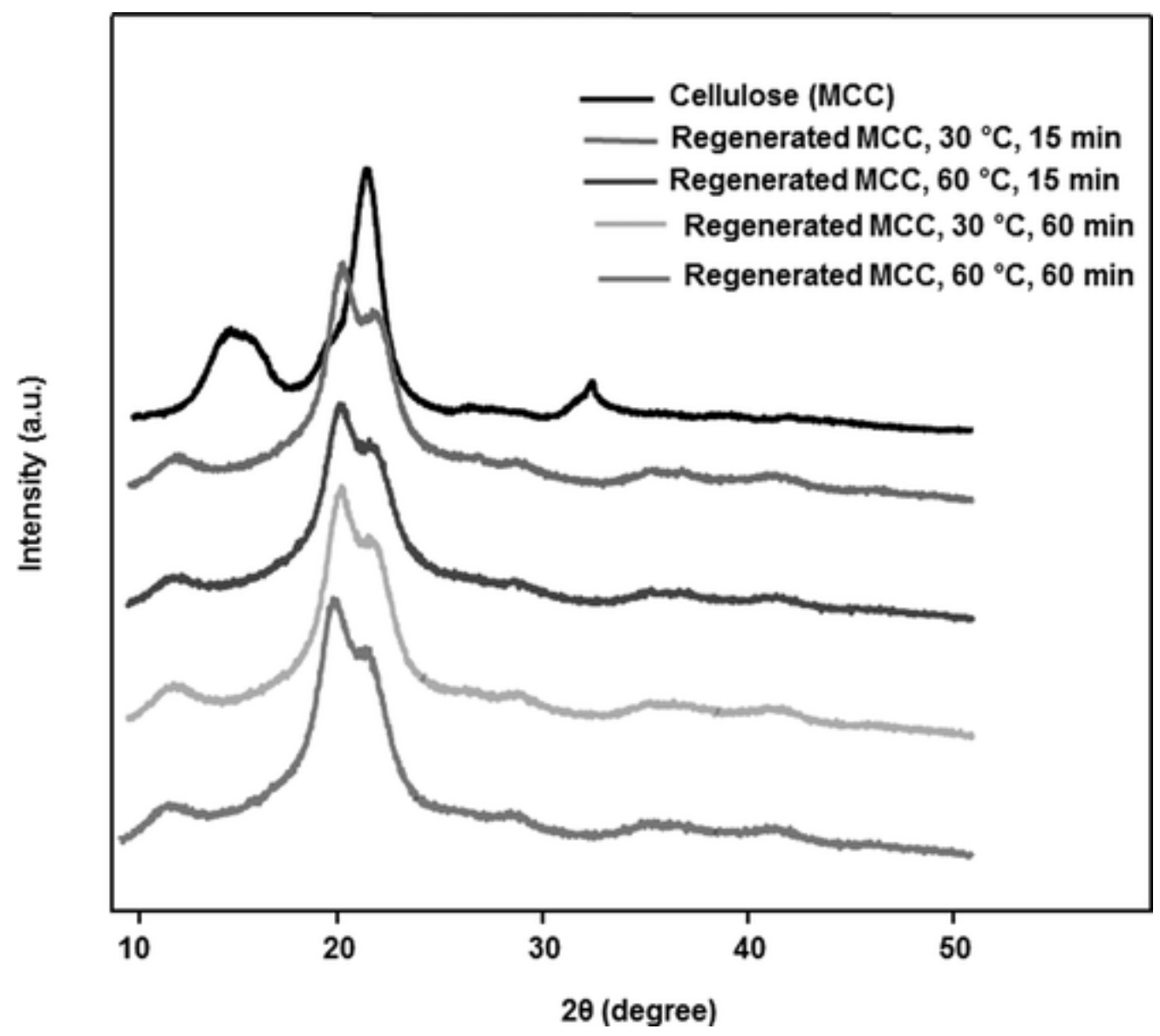

Figure 8. X-ray diffraction patterns of cellulose (MCC) and regenerated cellulose for different solubilization times (15 and $60 \mathrm{~min}$ ) and temperatures $\left(30\right.$ and $60^{\circ} \mathrm{C}$ ).

\section{Conclusions}

We have reported an optimization study on the $\mathrm{DBU} / \mathrm{CO}_{2}$ switchable solvent system for cellulose solubilization. Upon optimization, we have been able to achieve complete cellulose solubilization, as confirmed by XRD after cellulose regeneration, within $10-15 \mathrm{~min}$ at $30^{\circ} \mathrm{C}$ using $\mathrm{CO}_{2}$ at moderately low pressures (2-5 bar). Furthermore, we successfully trapped the intermediate carbonate formed, leading to formation of cellulose carbonate, hence unambigiously proving, for the first time, the existence of the in situ generated carbonate anion intermediate. As demonstrated, this optimized solvent system and its understanding allows for the design of novel cellulose derivatization strategies in homogeneous solution as well as improved cellulose regeneration strategies.

\section{Acknowledgment}

The authors thank Dr. Eric Lebraud for the XRD measurements. K.N.O. would like to thank the EU for Ph.D. funding under the Horizon 2020 Marie Curie ITN Project EJD-FunMat (Project ID: 6416).

\section{References}

1. Klemm, D.; Heublein, B.; Fink, H.-P.; Bohn, A. Cellulose: Fascinating biopolymer and sustainable raw material Angew. Chem., Int. Ed. 2005, 44, 3358- 3393DOI: 10.1002/anie.200460587

2. Bochek, A. M. Effect of Hydrogen Bonding on Cellulose Solubility in Aqueous and Nonaqueous Solvents Russ. J. Appl. Chem. 2003, 76, 1711- 1719DOI: 10.1023/B:RJAC.0000018669.88546.56 
3. McCormick, C. L.; Dawsey, T. R. Preparation of cellulose derivatives via ring-opening reactions with cyclic reagents in lithium chloride/N,N-dimethylacetamide Macromolecules 1990, 23, 3606-3610DOI: 10.1021/ma00217a011

4. Fink, H.-P.; Weigel, P.; Purz, H. J.; Ganster, J. Structure formation of regenerated cellulose materials from NMMOsolutions Prog. Polym. Sci. 2001, 26, 1473-1524DOI: 10.1016/S0079-6700(01)00025-9

5. Heinze, T.; Dicke, R.; Koschella, A.; Kull, A. H.; Klohr, E.-A.; Koch, W. Effective preparation of cellulose derivatives in a new simple cellulose solvent Macromol. Chem. Phys. 2000, 201, 627-631DOI: 10.1002/(SICI)15213935(20000301)201:6<627::AID-MACP627>3.0.CO;2-Y

6. Swatloski, R. P.; Spear, S. K.; Holbrey, J. D.; Rogers, R. D. Dissolution of Cellose with lonic Liquids J. Am. Chem. Soc. 2002, 124, 4974- 4975DOI: 10.1021/ja025790m

7. Mäki-Arvela, P.; Anugwom, I.; Virtanen, P.; Sjöholm, R.; Mikkola, J. P. Dissolution of lignocellulosic materials and its constituents using ionic liquids-A review Ind. Crops Prod. 2010, 32, 175-201DOI: 10.1016/j.indcrop.2010.04.005

8. Gericke, M.; Fardim, P.; Heinze, T. lonic liquids-Promising but challenging solvents for homogeneous derivatization of cellulose Molecules 2012, 17, 7458- 7502DOI: 10.3390/molecules17067458

9. Jessop, P. G.; Heldebrant, D. J.; Li, X.; Eckert, C. A.; Liotta, C. L. Green chemistry: Reversible nonpolar-to-polar solvent Nature 2005, 436, 1102DOI: 10.1038/4361102a

10. Xie, H.; Yu, X.; Yang, Y.; Zhao, Z. K. Capturing $\mathrm{CO}_{2}$ for cellulose dissolution Green Chem. 2014, 16, 2422- 2427DOI: 10.1039/C3GC42395F

11. Zhang, Q.; Oztekin, N. S.; Barrault, J.; De Oliveira Vigier, K.; Jérôme, F. Activation of microcrystalline cellulose in a $\mathrm{CO}_{2}$-based switchable system ChemSusChem 2013, 6, 593- 596DOI: 10.1002/cssc.201200815

12. Nanta, P.; Skolpap, W.; Kasemwong, K.; Shimoyama, Y. Dissolution and modification of cellulose using highpressure carbon dioxide switchable solution J. Supercrit. Fluids 2017, 130, 84-90DOI: 10.1016/j.supflu.2017.07.019

13. Wang, J.; Xue, Z.; Yan, C.; Li, Z.; Mu, T. Fine regulation of cellulose dissolution and regeneration by low pressure $\mathrm{CO}_{2}$ in DMSO/organic base: Dissolution behavior and mechanism Phys. Chem. Chem. Phys. 2016, 18, 32772- 32779DOI: 10.1039/C6CP05541A

14. Yang, Y.; Xie, H.; Liu, E. Acylation of cellulose in reversible ionic liquids Green Chem. 2014, 16, 3018- 3023DOI: 10.1039/C4GC00199K

15. Song, L.; Yang, Y.; Xie, H.; Liu, E. Cellulose Dissolution and In Situ Grafting in a Reversible System using an Organocatalyst and Carbon Dioxide ChemSusChem 2015, 8, 3217-3221DOI: 10.1002/cssc.201500378

16. Carrera, G. V.S.M.; Jordão, N.; Branco, L. C.; Nunes da Ponte, $\mathrm{M}$. $\mathrm{CO}_{2}$ capture and reversible release using monosaccharides and an organic superbase J. Supercrit. Fluids 2015, 105, 151- 157DOI: 10.1016/j.supflu.2015.02.015

17. Heldebrant, D. J.; Jessop, P. G.; Thomas, C. A.; Eckert, C. A.; Liotta, C. L. The reaction of 1,8diazabicyclo5.4.0undec-7-ene (DBU) with carbon dioxide J. Org. Chem. 2005, 70, 5335-5338DOI: 10.1021/jo0503759

18. Alves, M.; Grignard, B.; Gennen, S.; Detrembleur, C.; Jerome, C.; Tassaing, T. Organocatalytic synthesis of biobased cyclic carbonates from $\mathrm{CO}_{2}$ and vegetable oils RSC Adv. 2015, 5, 53629- 53636DOI: 10.1039/C5RA10190E 
19. Shi, M.; Shen, Y.-M. Synthesis of Mixed Carbonates via a Three-Component Coupling of Alcohols, $\mathrm{CO}_{2}$, and Alkyl Halides in the Presence of $\mathrm{K}_{2} \mathrm{CO}_{3}$ and Tetrabutylammonium lodide Molecules 2002, 7, 386-393DOI: $10.3390 / 70400386$

20. King, A. W. T.; Jalomäki, J.; Granström, M.; Argyropoulos, D. S.; Heikkinen, S.; Kilpeläinen, I. A new method for rapid degree of substitution and purity determination of chloroform-soluble cellulose esters, using ${ }^{31} \mathrm{P} N M R$ Anal. Methods 2010, 2, 1499DOI: 10.1039/c0ay00336k

21. Heldebrant, D. J.; Yonker, C. R.; Jessop, P. G.; Phan, L. Organic liquid $\mathrm{CO}_{2}$ capture agents with high gravimetric $\mathrm{CO}_{2}$ capacity Energy Environ. Sci. 2008, 1, 487-493DOI: 10.1039/b809533g

22. Andanson, J.-M.; Pádua, A. A. H.; Costa Gomes, M. F. Thermodynamics of cellulose dissolution in an imidazolium acetate ionic liquid Chem. Commun. (Cambridge, U. K.) 2015, 51, 4485-4487DOI: 10.1039/C4CC10249E

23. Elschner, T.; Kötteritzsch, M.; Heinze, T. Synthesis of cellulose tricarbonates in 1-butyl-3-methylimidazolium chloride/pyridine Macromol. Biosci. 2014, 14, 161- 165DOI: 10.1002/mabi.201300345

24. Labafzadeh, S. R.; Helminen, K. J.; Kilpeläinen, I.; King, A. W. T. Synthesis of cellulose methylcarbonate in ionic liquids using dimethylcarbonate ChemSusChem 2015, 8, 77-81DOI: 10.1002/cssc.201402794

25. Pang, J.-H.; Liu, X.; Wu, M.; Wu, Y.-Y.; Zhang, X.-M.; Sun, R.-C. Fabrication and Characterization of Regenerated Cellulose Films Using Different lonic Liquids J. Spectrosc. 2014, 2014, 1- 8DOI: 10.1155/2014/214057 
Support Information for:

\section{Detailed understanding of the $\mathrm{DBU} / \mathrm{CO}_{2}$ switchable solvent system for cellulose solubilization and derivatization}

Kelechukwu N. Onwukamike, ${ }^{a, b}$ Thierry Tassaing, ${ }^{c}$ Stéphane Grelier, ${ }^{b}$ Etienne Grau, ${ }^{b}$ Henri

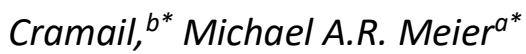

${ }^{a}$ Institute of Organic Chemistry (IOC), Materialwissenschaftliches Zentrum (MZE), Karlsruhe Institute of Technology (KIT), Straße am Forum 7, 76131 Karlsruhe, Germany; Email:

m.a.r.meier@kit.edu; web: www.meier-michael.com

${ }^{b}$ Laboratoire de Chimie des Polymères Organiques, Université de Bordeaux, UMR5629, CNRS Bordeaux INP - ENSCBP, 16 Avenue Pey-Berland, 33607 Pessac Cedex France

c Institut des Sciences Moléculaires, U.M.R. 5255 CNRS -

Université de Bordeaux, 351, Cours de la Libération 33405 Talence-France

I: FT-IR monitoring of stability of in-situ carbonate of octanol with temperature using DBU, MTBD and TMG as super bases

II: FT-IR monitoring of cellulose solubilization for pressure and temperature optimization

III: Concentration study of cellulose solubilization at various temperature

IV: Concentration study of octanol

V: Characterization of synthesized model octanol carbonate

VI; Characterization of synthesized cellulose carbonate 
I: FT-IR monitoring of stability of in-situ carbonate of octanol with temperature using DBU, MTBD and TMG as super bases

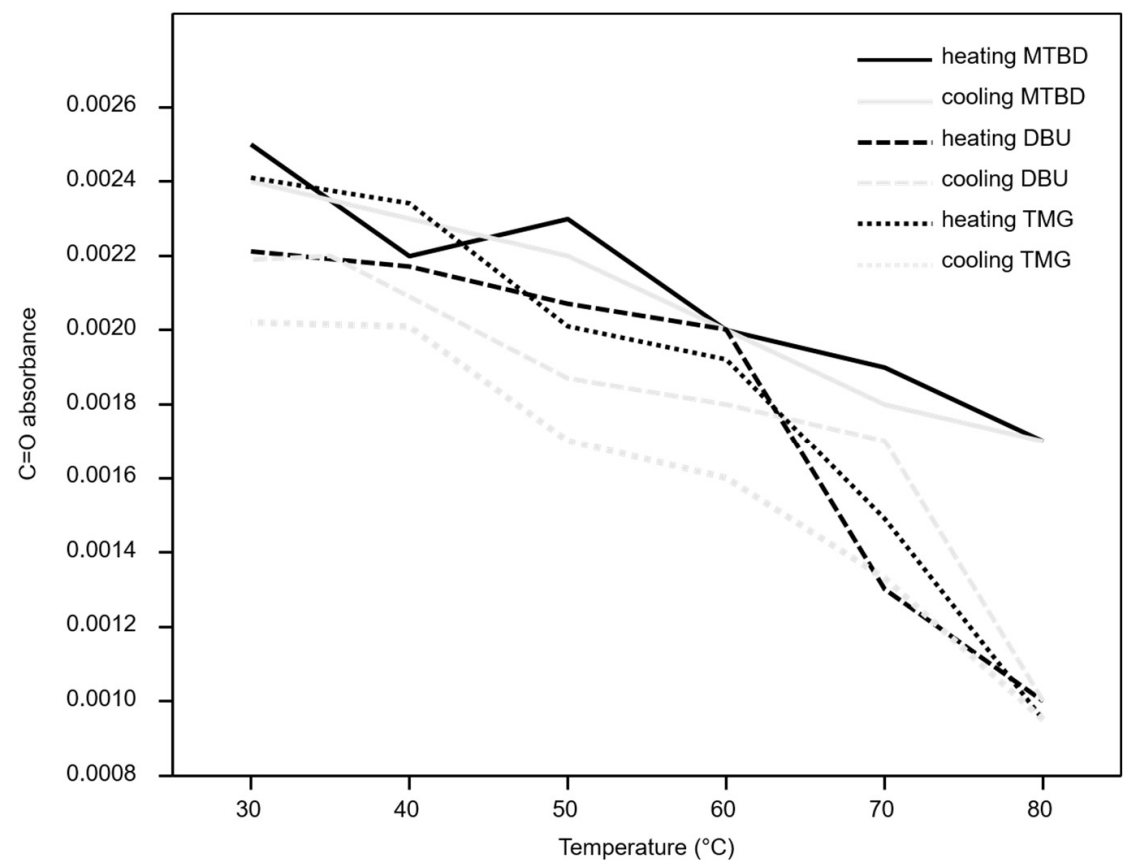

Figure S1: FT-IR C=O absorbance at $1665 \mathrm{~cm}^{-1}$ during stability study of in-situ formed carbonate of octanol at different temperatures using DBU, MTBD and TMG as super bases (conditions: 20 bar $\left.\mathrm{CO}_{2}, 30^{\circ} \mathrm{C}\right)$. 
II: FT-IR monitoring of cellulose solubilization for pressure and temperature optimization

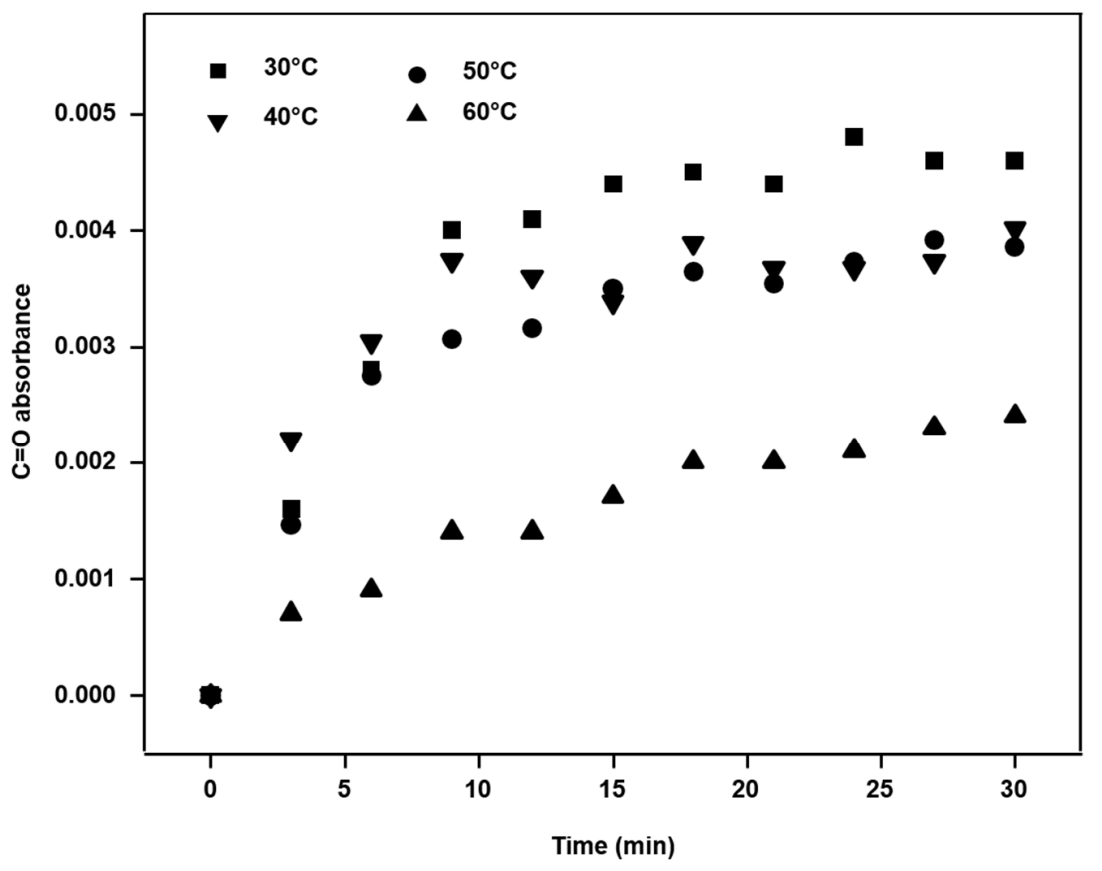

Figure S2: FT-IR C $=0$ absorbance at $1665 \mathrm{~cm}^{-1}$ during cellulose $(3 \%(w / w))$ solubilization with DBU as super base and 10 bar $\mathrm{CO}_{2}$ at different temperatures observed over time.

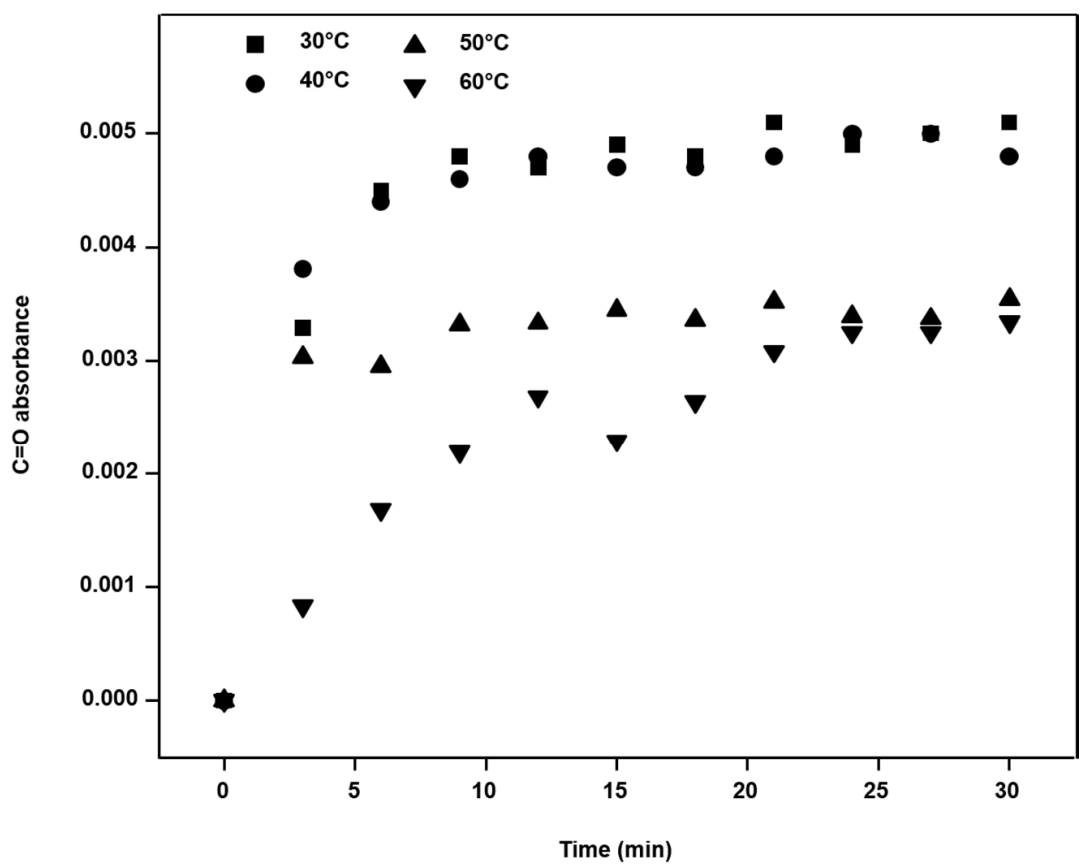

Figure S3: FT-IR C =O absorbance at $1665 \mathrm{~cm}^{-1}$ during cellulose $(3 \%(w / w))$ solubilization with DBU as super base and 20 bar $\mathrm{CO}_{2}$ at different temperatures observed over time. 


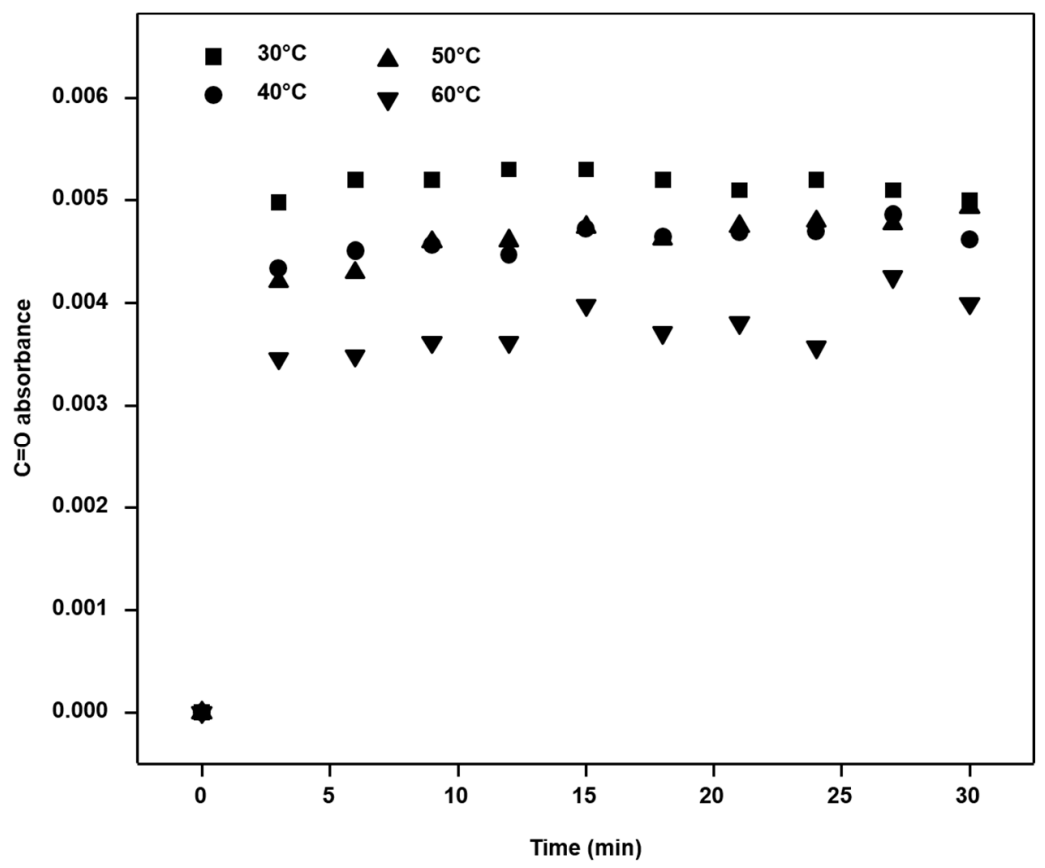

Figure S4: FT-IR C $=0$ absorbance at $1665 \mathrm{~cm}^{-1}$ during cellulose $(3 \%(w / w))$ solubilization with DBU as super base and 40 bar $\mathrm{CO}_{2}$ at different temperatures observed over time.

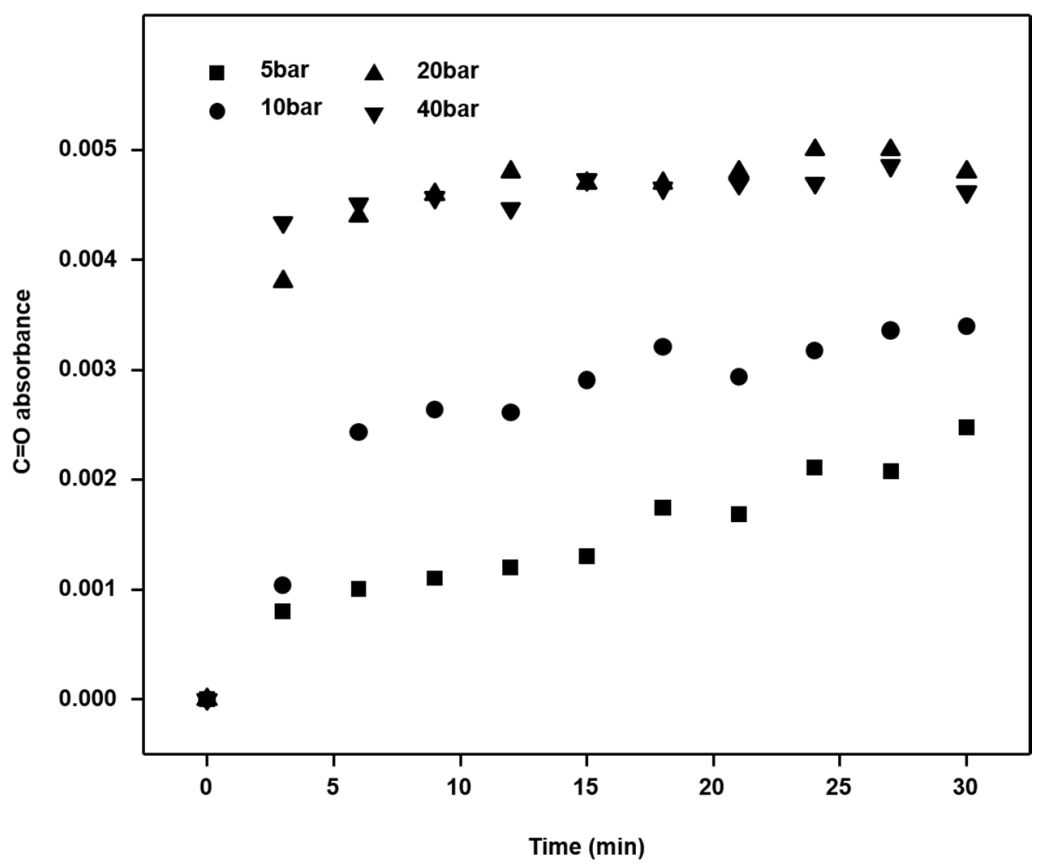

Figure S5: $F T-I R C=O$ absorbance at $1665 \mathrm{~cm}^{-1}$ during cellulose $(3 \%(w / w))$ solubilization with DBU as super base at $40^{\circ} \mathrm{C}$ at different $\mathrm{CO}_{2}$ pressures (in bar) observed over time. 


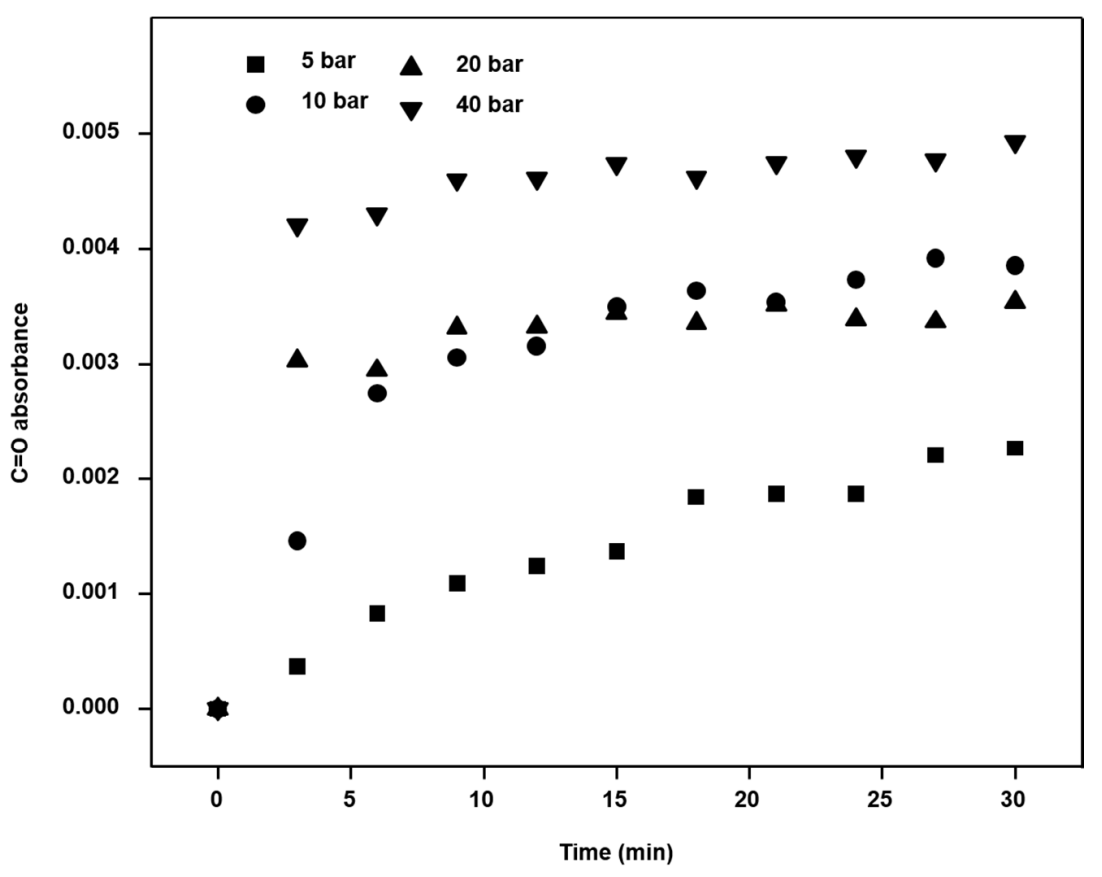

Figure S6: $F T$-IR $C=O$ absorbance at $1665 \mathrm{~cm}^{-1}$ during cellulose $(3 \%(w / w))$ solubilization with DBU as super base at $50^{\circ} \mathrm{C}$ at different $\mathrm{CO}_{2}$ pressures (in bar) observed over time.

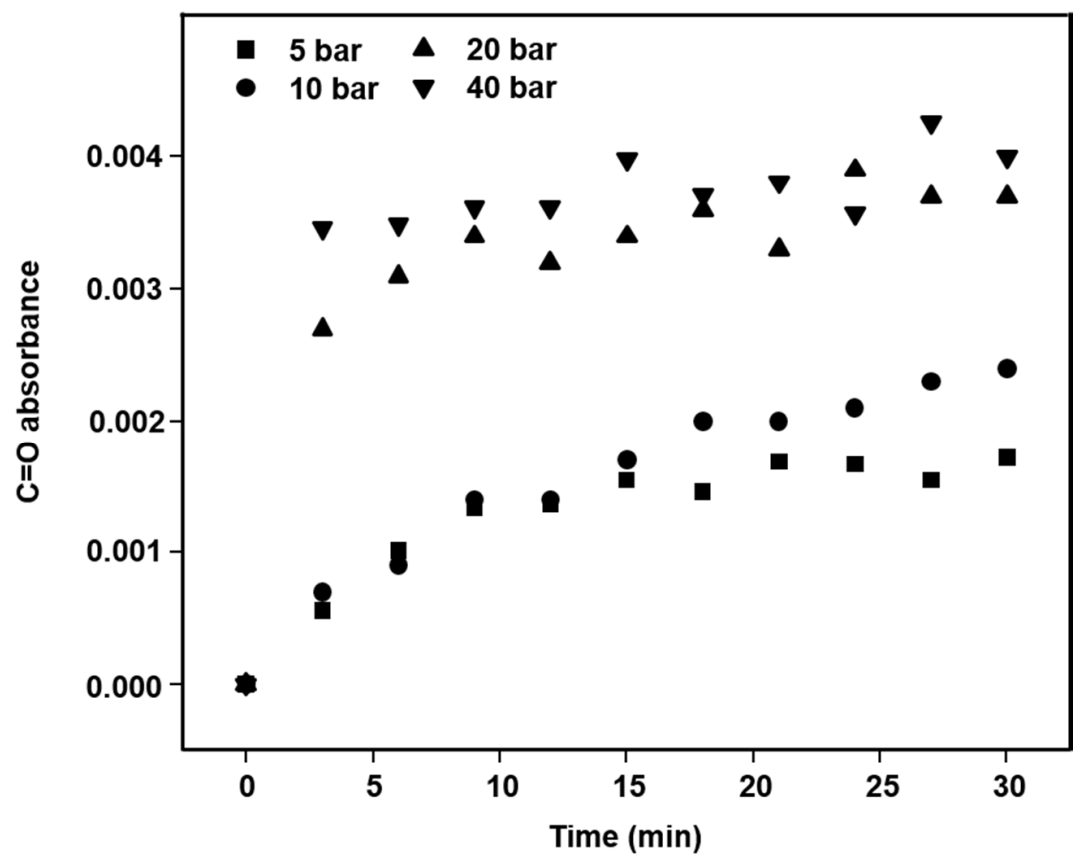

Figure S7: $F T$-IR C $=O$ absorbance at $1665 \mathrm{~cm}^{-1}$ during cellulose $(3 \%(w / w))$ solubilization with DBU as super base at $60^{\circ} \mathrm{C}$ at different $\mathrm{CO}_{2}$ pressures (in bar) observed over time. 
III: Concentration study of cellulose solubilization

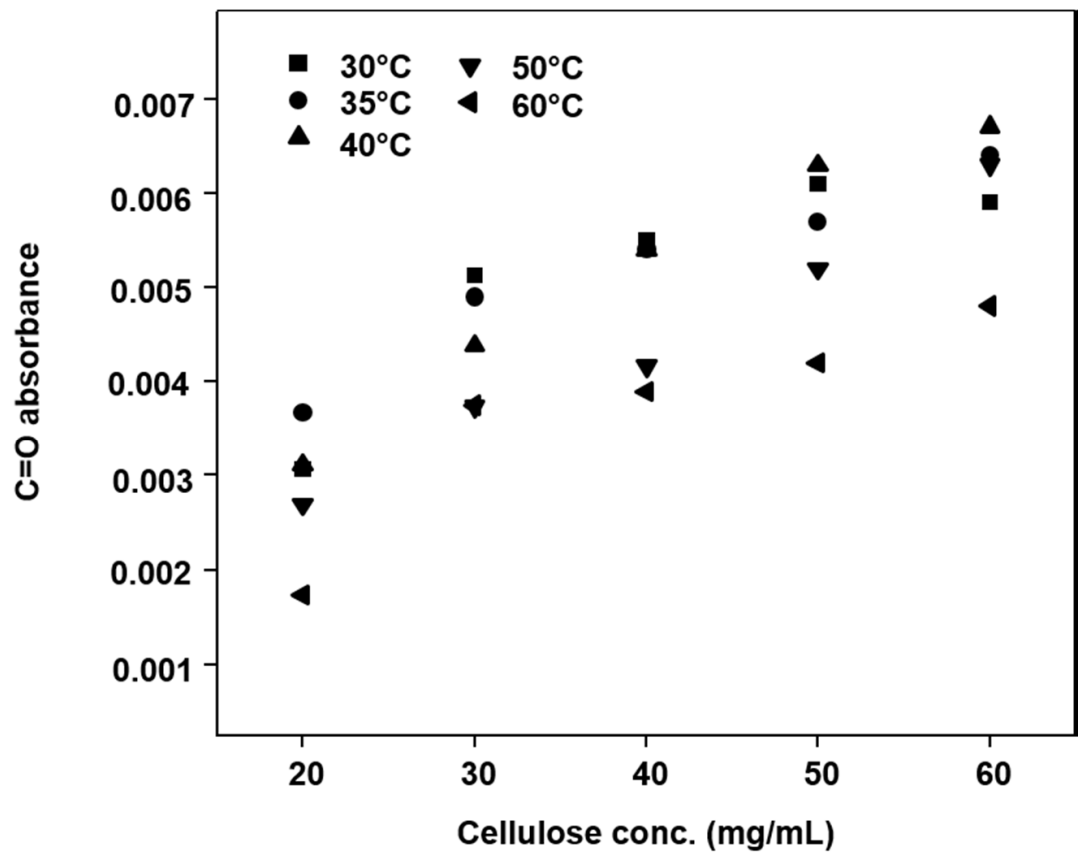

Figure S8: $F T-I R C=O$ absorbance at $1665 \mathrm{~cm}^{-1}$ during cellulose solubilization using $D B U$ as super base after 20 bar of $\mathrm{CO}_{2}$ applied for 15 minutes at various temperatures $\left(30,35,40,50,60^{\circ} \mathrm{C}\right)$ and varying cellulose concentration. 
IV: Concentration study of octanol

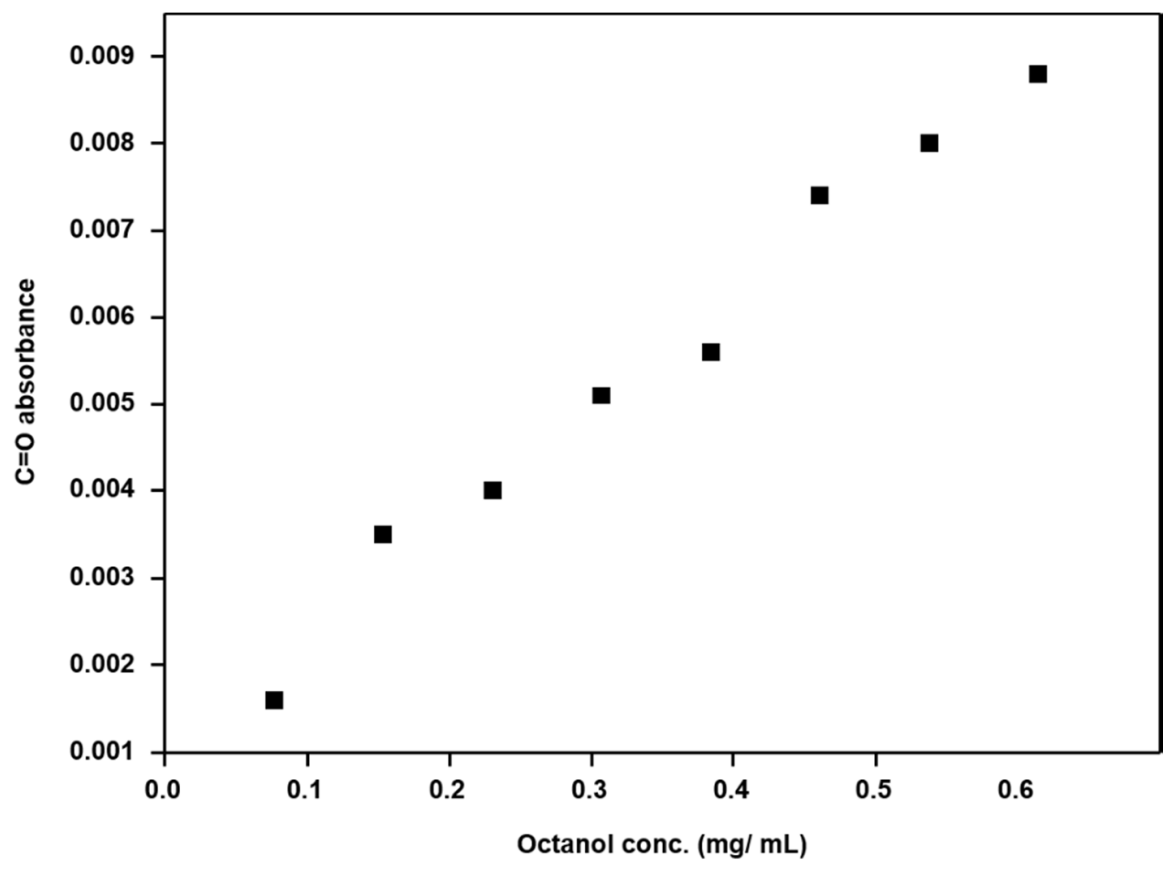

Figure S9: $F T$-IR $C=O$ absorbance at $1665 \mathrm{~cm}^{-1}$ during variation in octanol concentration using $D B U$ as super base after 20 bar of $\mathrm{CO}_{2}$ applied for 15 minutes at $30^{\circ} \mathrm{C}$.

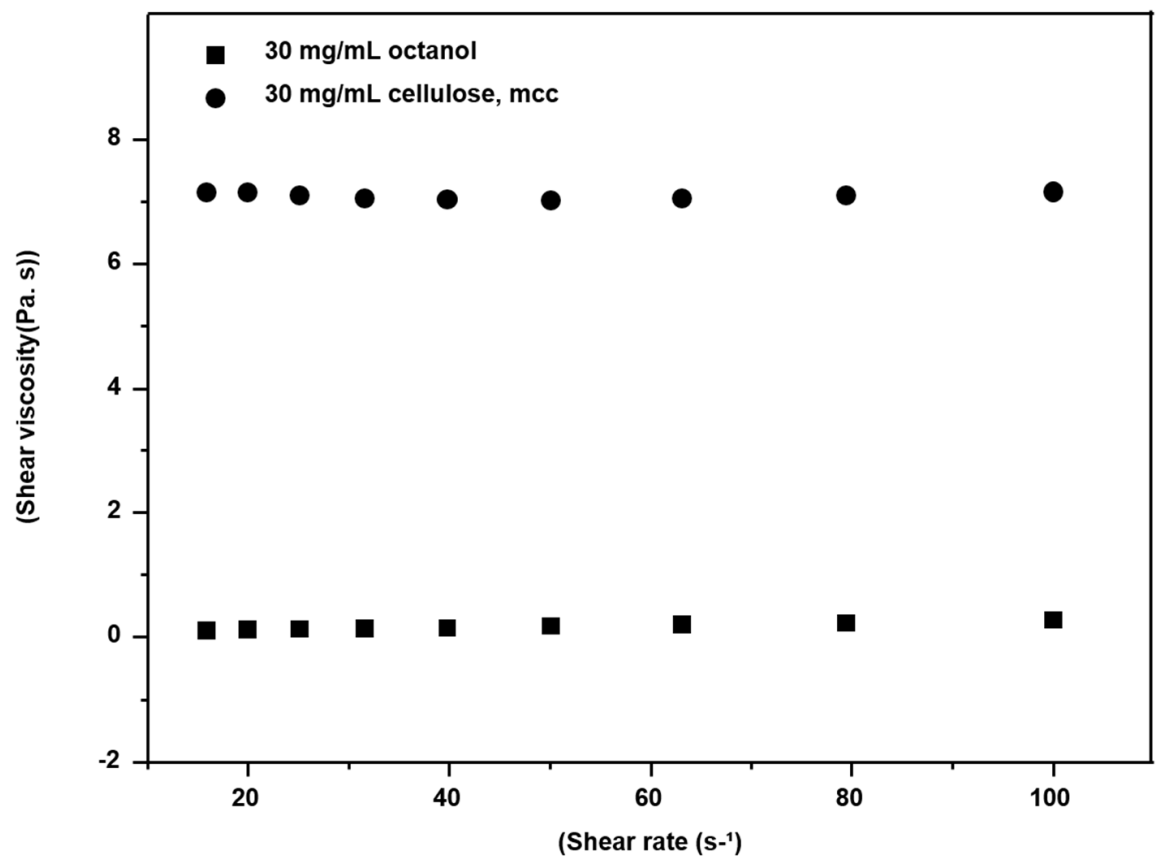

Figure S10: Viscosity measurement comparison between octanol and cellulose in a DBU-DMSO$\mathrm{CO}_{2}$ solvent mixture at concentration of $30 \mathrm{mg} / \mathrm{mL}$. 
V: Characterization of synthesized model octanol carbonate

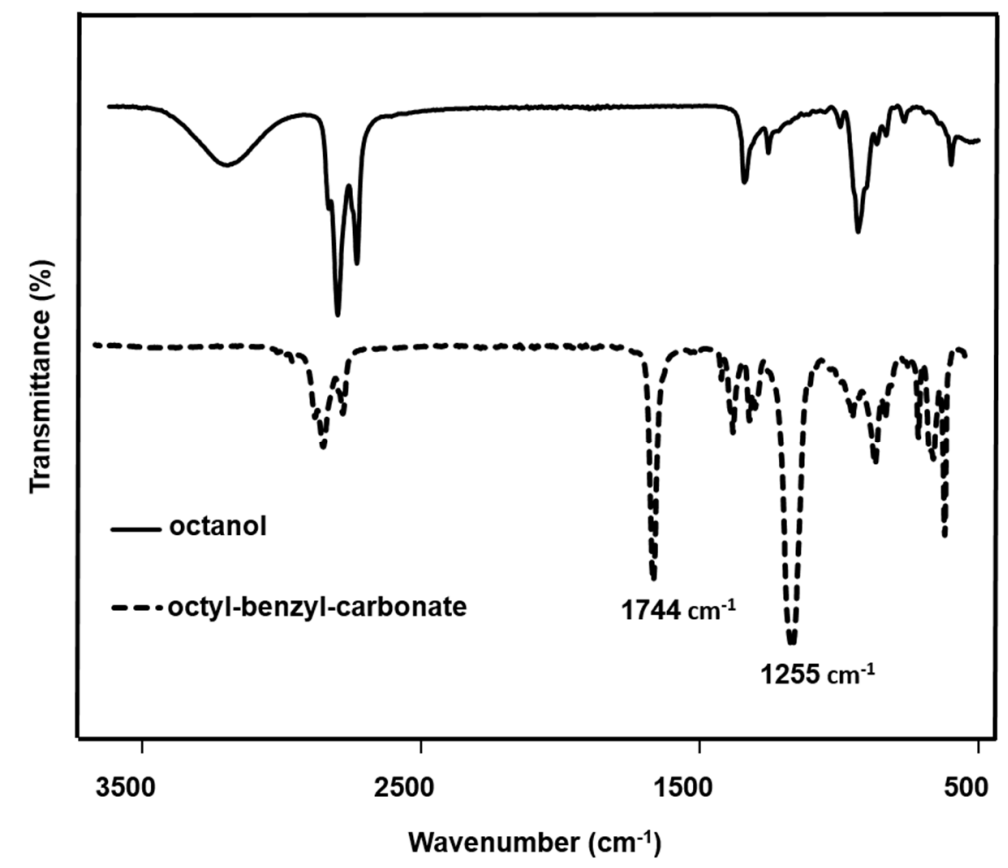

Figure S11: FT-IR spectra of octanol and octyl-benzyl-carbonate.

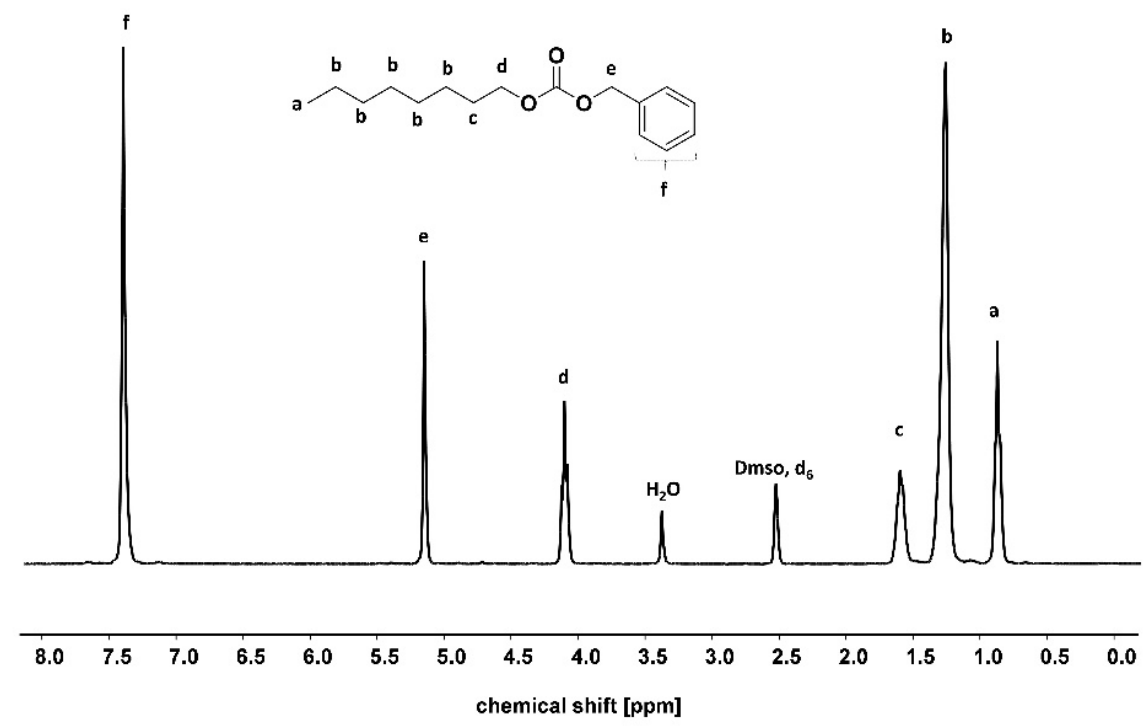

Figure S12: ${ }^{1} H$ NMR spectrum of octyl-benzyl-carbonate. 


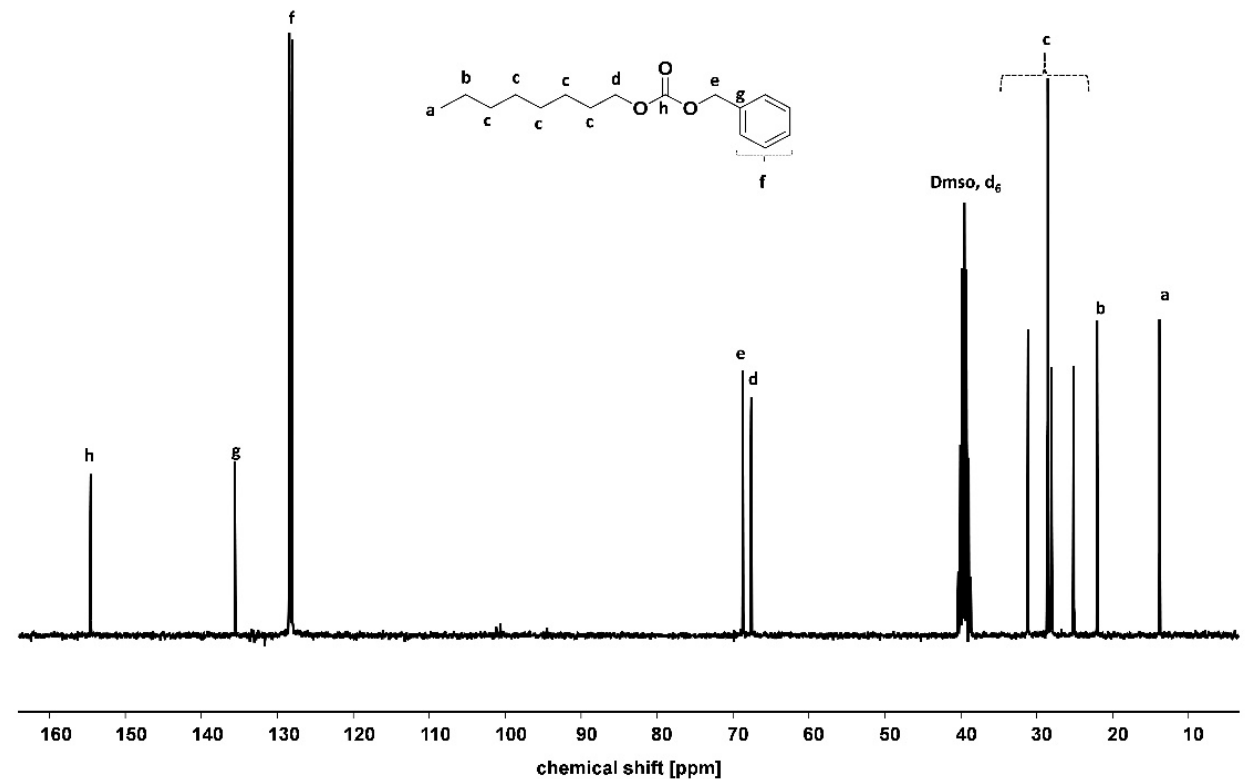

Figure S13: ${ }^{13}$ C NMR spectrum of octyl-benzyl-carbonate. 
VI: Characterization of synthesized cellulose carbonate

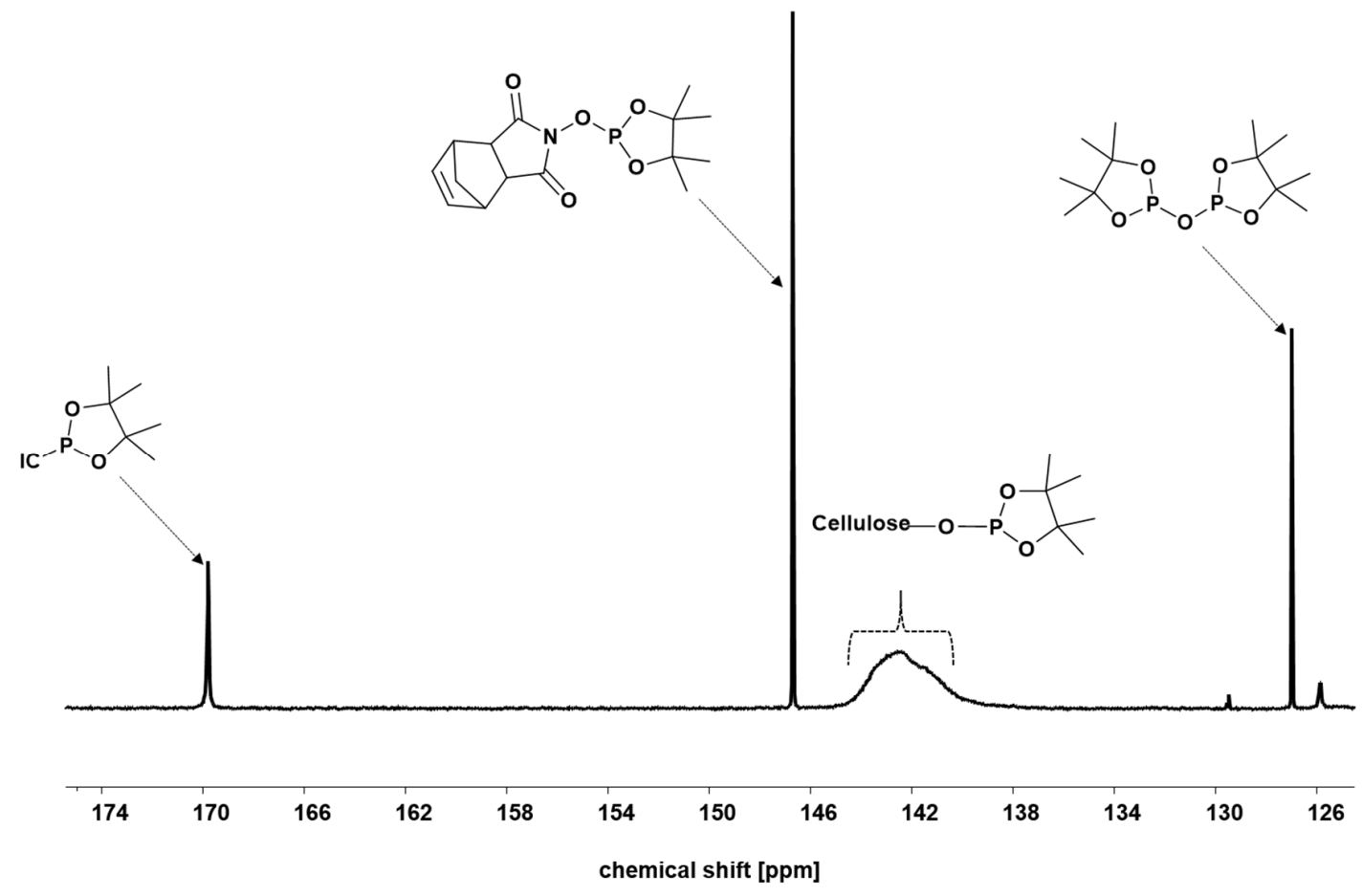

Figure S14: ${ }^{31} P$ NMR of cellulose-benzyl-carbonate for DS determination.
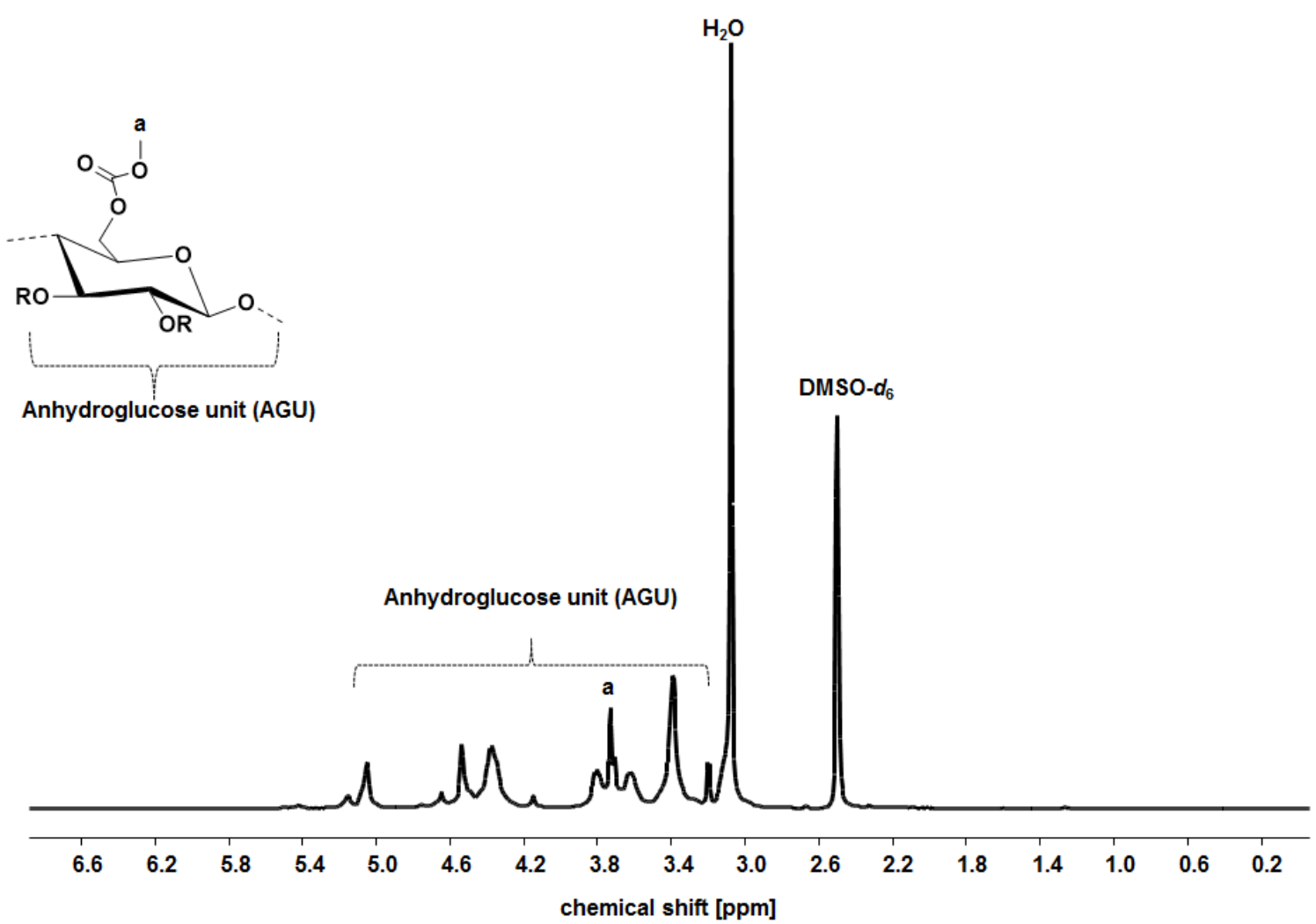

Figure S15: ${ }^{1} \mathrm{H}$ NMR spectrum of cellulose-methyl-carbonate measured in DMSO $\left(d_{6}\right)$ at $80{ }^{\circ} \mathrm{C}$. 


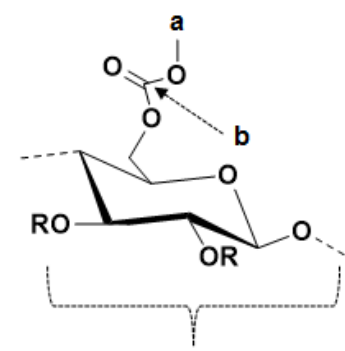

Anhydroglucose unit (AGU)

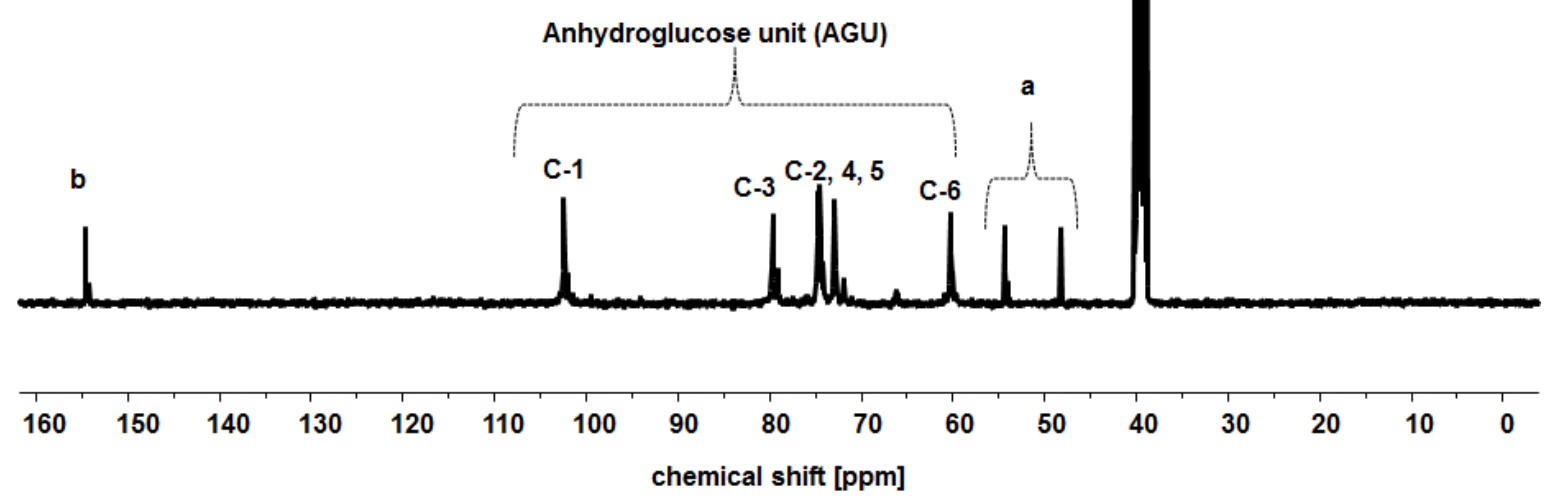

Figure S16: ${ }^{13} \mathrm{C}$ NMR of cellulose-methyl-carbonate measured in DMSO (d 6 ) at $80{ }^{\circ} \mathrm{C}$. 